Geosci. Model Dev. Discuss., https://doi.org/10.5194/gmd-2018-68

Manuscript under review for journal Geosci. Model Dev.

Discussion started: 2 May 2018

(c) Author(s) 2018. CC BY 4.0 License.

\title{
Marine biogeochemical cycling and climate-carbon cycle feedback simulated by the NUIST Earth System Model: NESM-2.0.1
}

\author{
Yifei Dai ${ }^{1}$, Long $\mathrm{Cao}^{2}$, Bin Wang ${ }^{1,3}$ \\ ${ }^{1}$ Earth System Modeling Center, and Key Laboratory of Meteorological Disaster of Ministry of Education, Nanjing \\ University of Information Science and technology, Nanjing 210044, China \\ ${ }^{2}$ Department of Atmospheric Sciences, School of Earth Sciences, Zhejiang University, Hangzhou 310027, China \\ ${ }^{3}$ Department of Atmospheric Sciences and Atmosphere-Ocean Research Center, University of Hawaii, Honolulu HI 96822, \\ USA
}

*Correspondence: longcao@zju.edu.cn

Abstract. In this study, we evaluate the performance of Nanjing University of Information Science \& Technology Earth System Model, version 2.0.1 (hereafter NESM-2.0.1). We focus on model simulated historical and future oceanic $\mathrm{CO}_{2}$ uptake, and analyze the effect of global warming on model-simulated oceanic $\mathrm{CO}_{2}$ uptake. Compared with available observations and data-based estimates, NESM-2.0.1 reproduces reasonably well large-scale ocean carbon-related fields, including nutrients (phosphate, nitrite and silicate), chlorophyll, and net primary production. However, some noticeable discrepancies between model simulations and observations are found in the deep ocean and coastal regions. Model-simulated current-day oceanic $\mathrm{CO}_{2}$ uptake compares well with data-based estimate. From pre-industrial time to 2011, modeled cumulative $\mathrm{CO}_{2}$ uptake is 144 $\mathrm{PgC}$, compared with data-based estimates of $155 \pm 30 \mathrm{PgC}$. Diagnosed from the end of the benchmark $1 \%$ per year $\mathrm{CO}_{2}$ increase simulations, carbon-climate feedback parameter, which represents the sensitivity of ocean $\mathrm{CO}_{2}$ uptake to climate change, is -7.1 $\mathrm{PgC} / \mathrm{K}$; Carbon-concentration feedback parameter, which represents the sensitivity of ocean $\mathrm{CO}_{2}$ uptake to increase in atmospheric $\mathrm{CO}_{2}$ is $0.81 \mathrm{PgC} / \mathrm{ppm}$. These two feedback parameters diagnosed from model simulations are consistent with the mean value diagnosed from the CMIP5 (Coupled Model Intercomparison Project phase 5) model simulations under the same $1 \%$ per year $\mathrm{CO}_{2}$ simulations $(-7.8 \mathrm{PgC} / \mathrm{K}$ and $0.80 \mathrm{PgC} / \mathrm{ppm}$, respectively). Our results demonstrate that NESM-2.0.1 can be used as a useful tool in the investigation of feedback interactions between the ocean carbon cycle, atmospheric $\mathrm{CO}_{2}$, and climate change.

\section{Introduction}

Global carbon cycle plays an important role in the climate system. The increase in atmospheric carbon dioxide $\left(\mathrm{CO}_{2}\right)$ is responsible for a large part of observed increase in global mean surface temperature (Ciais et al., 2013). From 1750 to 2016, about $645 \pm 80 \operatorname{PgC}\left(1 \mathrm{PgC}=10^{15}\right.$ gram carbon $)$ of anthropogenic carbon has been emitted to the atmosphere, including $420 \pm 20$ $\mathrm{PgC}$ from fossil fuels and industry and $225 \pm 75 \mathrm{PgC}$ from land-use-change (Le Quéré et al., 2017). This $\mathrm{CO}_{2}$ emission causes atmospheric $\mathrm{CO}_{2}$ concentration to increase by $45 \%$ from an annual meanpreindustrial value of $\sim 277$ parts per million (ppm) 
Geosci. Model Dev. Discuss., https://doi.org/10.5194/gmd-2018-68

Manuscript under review for journal Geosci. Model Dev.

Discussion started: 2 May 2018

(c) Author(s) 2018. CC BY 4.0 License.

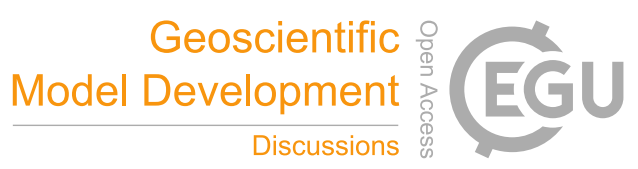

(c) (i)

(Joos and Spahni, 2008) to 404 ppm in 2016 (NOAA ESRL Global Monitoring Division, 2016).

The ocean carbon cycle is one of the main components of global carbon cycle. As a large carbon reservoir, the global ocean contains more than 50 times of carbon than that of the atmosphere (Menon et al., 2007). The global ocean also plays a key role in anthropogenic $\mathrm{CO}_{2}$ uptake (Ballantyne et al., 2012; Wanninkhof et al., 2013). Since preindustrial time to now, about $25 \%$ of anthropogenic $\mathrm{CO}_{2}$ (about $160 \pm 20 \mathrm{PgC}$ ) has been absorbed by the ocean (Le Quéré et al., 2017). The ocean carbon cycle involves many complex physical, chemical, and biological processes such as chemical reaction of water molecular with dissolved $\mathrm{CO}_{2}$, biological uptake of $\mathrm{CO}_{2}$ through photosynthesis by phytoplankton in the upper ocean, and transport of inorganic and organic carbon into the ocean interior (Sarmiento and Gruber, 2006).

Increase in atmospheric $\mathrm{CO}_{2}$, by perturbing atmospheric radiation balance, leads to climate change. Changes in atmospheric temperature, precipitation, evaporation, and wind, induces changes in ocean physical properties such as temperature, salinity, and ocean circulation. (Levitus et al., 2000; Gregory et al. 2005; Pierce et al., 2012). These changes in ocean physical properties in turn affect the ocean carbon cycle (Sarmiento and Gruber, 2006). For example, increasing temperature can directly decrease $\mathrm{CO}_{2}$ solubility and result in the reduction of ocean $\mathrm{CO}_{2}$ uptake (Najjar 1992; Teng et al., 1996). Changes in wind speed can also directly influence air-sea carbon exchange by changing gas transfer velocity (Wanninkhof 1992; Wanninkhof and Trinanes 2017). Previous studies also show that global warming would lead to a weakening of global thermohaline circulation and increase ocean stratification (Gregory et al. 2005), both of which result in a slower transport of carbon from the surface to the ocean interior, reducing ocean's uptake of anthropogenic $\mathrm{CO}_{2}$ (Cox et al., 2000; Zickfeld et al., 2008). Therefore, it is important to gain a good understanding of the potential effect of global warming on the ocean carbon cycle.

Friedlingstein et al., (2006) proposed that the response of oceanic uptake of atmospheric $\mathrm{CO}_{2}$ can be represented by the linear sum of two components: 1) carbon-concentration feedback, which refers to the response of ocean $\mathrm{CO}_{2}$ uptake to increasing atmospheric $\mathrm{CO}_{2}$ alone; 2) carbon-climate feedback, which refers to the response of ocean $\mathrm{CO}_{2}$ uptake to $\mathrm{CO}_{2}$-induced climate change alone. Adopting the above conceptual framework, Friedlingstein et al., (2006) analyzed the carbon-concentration and carbon-climate feedback from Coupled Climate-Carbon Cycle Model Intercomparison Project (C $\left.\mathrm{C}^{4} \mathrm{MIP}\right)$ results. Since the work of Friedlingstein et al., (2006), a number of studies have analyzed the magnitudes of the carbon-concentration and carbonclimate feedback and their interactions under different $\mathrm{CO}_{2}$ emission and concentration scenarios using CMIP5 model results (Gregory et al., 2009; Boer and Arora, 2009; Arora et al., 2013).

Given the importance of carbon cycle feedback in current and future global climate change, it is necessary to include the representation of global carbon cycle in Earth system models (Bretherton, 1985; Menon et al., 2007). In 2014, a new Earth system model, Nanjing University of Information Science and Technology Earth System Model version 1.0, was developed. NESM v1.0 reproduces realistic large-scale present-day climatic fields such as sea surface temperature (SST) and precipitation. Large-scale climate variability and climate mode such as El Niño-Southern Oscillation (ENSO) and Madden-Julian oscillation (MJO) are also well reproduced (Cao et al., 2015). Moreover, NESM v1.0 also shows good skills in simulation of Indian monsoon precipitation (Li et al., 2017). Recently, the new version of NESM-2.0.1 is developed based on NESM v2.0. In this new version, Pelagic Interactions Scheme for Carbon and Ecosystem Studies (PISCES v2) is coupled to the ocean circulation 
Geosci. Model Dev. Discuss., https://doi.org/10.5194/gmd-2018-68

Manuscript under review for journal Geosci. Model Dev.

Discussion started: 2 May 2018

(c) Author(s) 2018. CC BY 4.0 License.

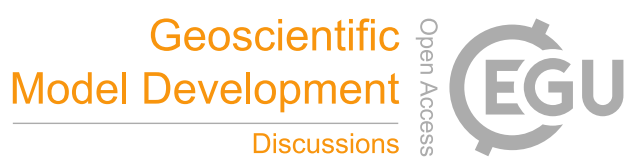

(c) (i)

model to represent the ocean biogeochemical processes (Aumont et al., 2015). PISCES can be used for both regional and global simulation of lower tropic levels of marine ecosystems and ocean carbon cycle (Bopp et al., 2005; Resplandy et al., 2012) The Earth System model of the Institute Pierre et Simon Lappace and Centre National de Recherche en Météorologie (IPPSL-CNRM) ESM, which uses PISCES to represent the ocean carbon cycle, contributed to CMIP5 (Séférian et al., 2013). In this study, we present the performance of the ocean carbon cycle component in NESM-2.0.1. In Section 2, we describe the model of NESM-2.0.1 with the focus on the ocean carbon cycle component, as well as the setup of simulation experiments. In Section 3, we present the model performance. We evaluate modeled nutrients and ecosystem fields against available observations in Section 3.1. In Section 3.2, we evaluate modeled oceanic uptake of anthropogenic $\mathrm{CO}_{2}$ during the historical period against data-based estimates. In Section 3.3, we analyze modeled carbon-concentration feedback and carbon-climate feedback under different $\mathrm{CO}_{2}$ concentration scenarios and compare our results with CMIP5 model results. Conclusion and discussions are given in Section 4.

\section{Method}

\subsection{Model}

\subsubsection{Framework of NESM-2.0.1}

Nanjing University of Information Science and Technology (NUIST) Earth System Model (NESM) is a comprehensive Earth System Model that is designed to study interactions between different components of the Earth climate system and its response to natural and anthropogenic forcing. NESM-2.0.1 is developed based on the framework of NESM v2 with active ocean biogeochemical cycle, and the physical components of NESM-2.0.1 is same as NESM v2. The physical components of the NESM are described in detailed in Cao et al., (2015). Here we briefly introduce its main features. NESM consists of three main component models, including European Centre Hamburg Atmospheric Model (ECHAM v5.3) (Roeckner et al., 2003), Nucleus for European Modeling of the Ocean version 3.4 (NEMO v3.4-revision 3814) (Madec and NEMO team, 2012) and Los Alamos sea-ice model version 4.1 (CICE v4.1) (Hunke and Lipsomb, 2010). The three component models are coupled by the Ocean-Atmosphere-Sea-Ice-Soil (OASIS v3.0) Model coupling Toolkit (OASIS3-MCT) (Larson et al. 2005). The atmospheric resolution used in NESM v2 is T42L31 which has a horizontal resolution of $\sim 2.8^{\circ}$ latitude by $2.8^{\circ}$ longitude and 31 vertical levels. The land surface model is a simple surface scheme that is implicitly coupled with the atmosphere, in which surface fluxes and temperature are computed using energy balance equation (Schulz et al., 2001). Surface albedo depends on background, snow, forest and canopy, and snow processes from canopy to soil are prognostically calculated (Roesch et al., 2001). A simple mixed-layer lake is also used. Ocean component runs with an ORCA2 global ocean configuration, which is a type of tripole grid. It is based on a 2 degree Mercator mesh and has 31 vertical levels with the thickness of ocean layer increasing from $10 \mathrm{~m}$ at the upper ocean to $500 \mathrm{~m}$ at $5000 \mathrm{~m}$ depth. A local transformation is applied in the Tropics to refine the resolution up to 0.5 degree at the Equator. Sea-ice component includes four vertical ice layers and one snow layer with a multi- 
Geosci. Model Dev. Discuss., https://doi.org/10.5194/gmd-2018-68

Manuscript under review for journal Geosci. Model Dev.

Discussion started: 2 May 2018

(c) Author(s) 2018. CC BY 4.0 License.

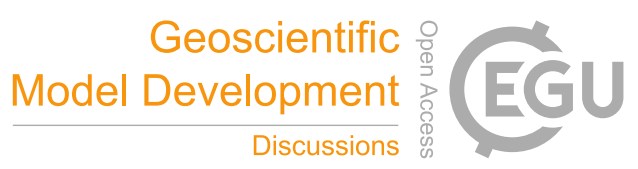

(c) (i)

layer thermodynamic scheme.

\subsubsection{Ocean biogeochemical component}

NESM-2.0.1 employs standard PISCES v2 code to represent the ocean biogeochemical cycle in the atmosphere-ocean-sea-ice modeling system. No modification is applied to biological parameters and their formulations in the source code. There are 24 prognostic tracers in total in NESM-2.0.1, including dissolved inorganic and organic carbon, alkalinity, chlorophyll, nutrients and etc. Total Variance Dissipation (TVD) scheme (Zalesak, 1979) is used to describe the advection of these tracers. Carbonate chemistry including air-sea $\mathrm{CO}_{2}$ exchange is formulated based on the Ocean Carbon-Cycle Model Intercomparison Project (OCMIP-2) protocol (more information can be access for free at http://ocmip5.ipsl.jussieu.fr/OCMIP/).

The inorganic and organic carbon cycle is simulated via the processes between nutrients, phytoplankton, and zooplankton.

These processes including phytoplankton growth and mortality, grazing by zooplankton, aggregation and remineralization of organic matter (Aumont et al., 2015). Growth rate of phytoplankton is limited by availability of nutrients, including phosphate, nitrate, silicate, iron, and ammonium. Also, phosphate, nitrate and carbon in phytoplankton are linked by a constant Redfield ratio. In NESM-2.0.1, the Redfield ratio of C: N: P is set to be 122:16:1 (Takahashi et al., 1985) and the $-\mathrm{O} / \mathrm{C}$ ratio is set to 1.34 (Kortzinger et al., 2001). In contrast, the Fe / C, Chlorophyll / C, and Silicon / C ratio are prognostically simulated by the model. Mortality and aggregation of phytoplankton is associated with the calcifying organisms and bigenic silica. In NESM$2.0 .1,50 \%$ of the calcified organisms are associated with the shell. As a consequence, $50 \%$ of the dying calcified biomass is routed to the fast sinking particulate organic matter (POM). The degradation of the particles depends on the local temperature and while the remineralization of depends on local oxygen concentration. For POM, a simple two-compartment scheme is used. In that case, POM is modeled using two tracers corresponding to the two size classes: smaller class (1-100 $\mu \mathrm{m})$ and larger class $(100-500 \mu \mathrm{m})$, which also differ from their sinking speed.

The exchange between sediments and the ocean interior at the bottom boundary can be represented either with or without a sediment model. In NESM-2.0.1, the sediment model is inactive, basic but different parameterizations are applied depending on tracers considered. For example, buried biogenic silica is assumed to balance the external source, buried POM is determined by the organic carbon sinking rate at the bottom, and all the particulate iron would buried into the sediment once they reach the ocean bottom. The amount of unburied parts dissolve back to ocean instantaneously. Expect the interior processes, the external sources of nutrients are also described as geochemical boundary conditions in NESM-2.0.1, including atmospheric dust deposition of iron and silicon, river recharge of nutrients, dissolved carbon, and alkalinity, atmospheric deposition of nitrogen, and sediment mobilization of sedimentary iron.

In addition, light penetration parameterization is regarded as an important factor which could influence ocean thermal structure. In NESM-2.0.1, incoming solar radiation is distributed among the upper ocean layers $(391 \mathrm{~m})$, and bio-model penetration parameterization scheme is used to calculate the distribution of solar radiation. In that case, solar radiation penetrate rate is dependent on modeled chlorophyll concentration in each ocean layer (Lengaigne et al., 2009). 
Geosci. Model Dev. Discuss., https://doi.org/10.5194/gmd-2018-68

Manuscript under review for journal Geosci. Model Dev.

Discussion started: 2 May 2018

(c) Author(s) 2018. CC BY 4.0 License.

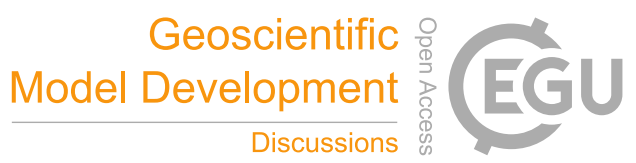

(c) (i)

\subsection{Simulations}

First, NESM-2.0.1 was spun up for 1500 years with all related parameters set to pre-industrial values including orbit parameters and greenhouse gases (GHGs) concentrations (280 ppm for $\mathrm{CO}_{2}, 720 \mathrm{ppb}$ for $\mathrm{CH}_{4}, 270 \mathrm{ppb}$ for $\mathrm{N}_{2} \mathrm{O}$, and 0 ppt for both $\mathrm{CFC}_{11}$

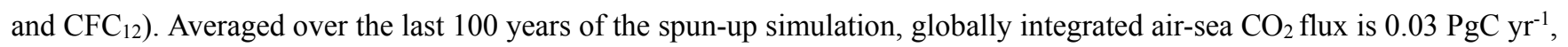
and the linear drift is $0.0006 \mathrm{PgC} \mathrm{yr}^{-1}$ per year, indicating that a quasi-equilibrium state has been reached for the global ocean carbon cycle. Meanwhile, global mean SST averaged over the last 100 years of spun-up simulation is 13.1 Celsius $\left({ }^{\circ} \mathrm{C}\right)$ with the linear drift of $0.001{ }^{\circ} \mathrm{C}$ per year, and ocean mean temperature $3.4^{\circ} \mathrm{C}$ with the linear drift of $0.0004{ }^{\circ} \mathrm{C}$ per year, indicating that ocean climate field has also reached a quasi-equilibrium state.

Using the end of the 1500-year spun simulation as the initial state of the nominal pre-industrial year of 1800 , the model is further integrated to year 2100 with prescribed time-series of atmospheric concentrations of GHGs, including $\mathrm{CO}_{2}, \mathrm{CH}_{4}, \mathrm{~N}_{2} \mathrm{O}$, and CFCs and aerosols, i.e. historical runs from year 1800 to 2005 and RCP8.5 scenario runs from 2006 to 2100 . In historical runs, prescribed concentrations of GHGs are taken from observational record (http://www.mpimet.mpg.de/en/science/observations-data ), and in RCP8.5 scenario runs, prescribed GHGs are taken from representative concentrations pathways of RCP 8.5 (Moss et al., 2010). In addition, following the protocol of CMIP5 (Taylor et al. 2012), we performed idealized 1\%/yr $\mathrm{CO}_{2}$ run (core 6.1 in CMIP5 experiment design), in which atmospheric $\mathrm{CO}_{2}$ is increased at a rate of $1 \%$ per year starting from the end state of pre-industrial control simulation with other GHGs concentration remaining at preindustrial level. The simulation lasted for 140 years until atmospheric $\mathrm{CO}_{2}$ concentration has quadrupled. Here we mainly focus on the ocean carbon cycle response and use prescribed atmospheric $\mathrm{CO}_{2}$ concentrations, and the feedback from the terrestrial carbon cycle is not considered.

20 To separate the effect of atmospheric $\mathrm{CO}_{2}$ and global warming on the ocean carbon cycle, for each of the three simulations above, three sensitivity experiments: biogeochemically coupled, radiatively coupled, and fully coupled were performed as summarized in Table 1. These types of simulations were also performed by previous studies that investigated the effect of $\mathrm{CO}_{2}$ and $\mathrm{CO}_{2}$-induced climate change on the global carbon cycle (Friedlingstein et al., 2006; Arora et al., 2013; Schwinger et al., 2014).

25 1) Biogeochemically coupled (BC) simulations in which the code of the ocean carbon cycle sees changing atmospheric $\mathrm{CO}_{2}$, but the code of atmospheric radiation sees constant pre-industrial concentration of $\mathrm{CO}_{2}$ and other GHGs as set in the spun-up simulation. In this way, the ocean carbon cycle is only affected by changing atmospheric $\mathrm{CO}_{2}$, but not GHG-induced climate change;

2) Radiatively coupled (RC) simulations in which the code of the ocean carbon cycle sees pre-industrial atmospheric $\mathrm{CO}_{2}$, but the code of atmospheric radiation sees changing concentration of atmospheric $\mathrm{CO}_{2}$ and other GHGs. In this way, the ocean carbon cycle is only affected by GHG-induced climate change, but not the direct effect of changing atmospheric $\mathrm{CO}_{2}$.

3) Fully-coupled (FC) simulations in which both the codes of the ocean carbon cycle and atmospheric radiation see changing concentrations of atmospheric $\mathrm{CO}_{2}$ and other GHGs. In this way, the ocean carbon cycle is affected by changes in both 
Geosci. Model Dev. Discuss., https://doi.org/10.5194/gmd-2018-68

Manuscript under review for journal Geosci. Model Dev.

Discussion started: 2 May 2018

(c) Author(s) 2018. CC BY 4.0 License.

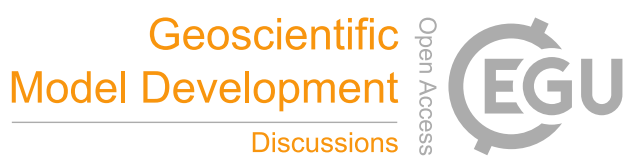

(c) (i)

atmospheric $\mathrm{CO}_{2}$ and $\mathrm{GHG}$-induced climate change.

In total, there are 10 different simulations in this study, including one fully coupled spin up simulation for 1500 years, three historical runs (FC, BC, and RC) from 1800 to 2005, three RCP8.5 runs (FC, BC, and RC) from 2006 to 2100, and three idealized $1 \% / \mathrm{yr} \mathrm{CO} 2$ runs (FC, BC, and RC) for 140 years.

\section{Results}

\subsection{Evaluation of NESM-2.0.1 simulated present-day ocean ecosystem}

In this section, we compare model-simulated ocean biogeochemical fields that are directly related to the ocean ecosystem and carbon cycle, including nutrients, chlorophyll, and net primary production (NPP) against available observational and databased estimates. A detailed description of the observational data used is given in Appendix A. To have a direct comparison between NESM-2.0.1 results and observations, we interpolate NESM-2.0.1 results onto the corresponding grids of observational data using the distance-weighted averaged remapping method, as detailed in Appendix A.

Nutrients limit the growth of phytoplankton and play a vital role in the ocean biogeochemical cycles. Figure 1 compares modelsimulated annual mean spatial distributions of macronutrients, including nitrate $(\mathrm{N})$, phosphate $(\mathrm{P})$, and silicate $(\mathrm{Si})$ during 1990s against WOA09 observations during the same period (Garcia, et al., 2010). As shown in Fig. 1, the model reproduces reasonably well the large-scale pattern of macronutrient distributions at ocean surface. Relatively high nutrient concentrations are found in the Southern Ocean, subarctic Pacific Ocean, and the mid-east Pacific Ocean where strong vertical mixing and upwelling bring nutrient-rich deep water to the surface (Whitney, 2011). Relatively low concentrations of nutrients are found in subtropical regions where the vertical mixing between surface and the deep ocean is relatively weak. Some noticeable discrepancies between model results and observations are noticed (Fig. 1). For example, modeled surface silicate concentrations are much higher than the observation in the Equatorial Pacific Ocean. Also, simulated surface phosphate concentration is lower than the observation in the Equatorial Pacific.

Figure 2 shows globally averaged vertical profiles of macro-nutrients during 1990s and WOA09 observations. In general, the concentrations of silicate, phosphate, and nitrate are more enriched in the deep ocean as a result of remineralization of organic matter in the ocean interior. NESM-2.0.1 simulates the vertical distribution of silicate reasonably well. However, the model underestimates the concentration of phosphate and nitrate between500 to $2000 \mathrm{~m}$ depth, and overestimates their concentrations below $\sim 2000 \mathrm{~m}$. The modeled-deficiencies of nutrient distributions is associated with the modeled deficiencies in the ocean dynamics or/and parameterizations of the ocean biological processes. The inclusion of natural radiocarbon $\left({ }^{14} \mathrm{C}\right)$ in the model, which is not implemented yet, would be useful in separating the effect of modeled ocean dynamics and biology (Stocker and Wright, 1996). We will further discuss this issue in the Section 4.

30 Figure 3 shows modeled spatial distribution of annual mean surface chlorophyll concentration during 1990s compared with SeaWifs observational data (Behrenfeld and Falkowski, 1997a, 1997b.). The model simulates reasonably well the large scale pattern of ocean surface chlorophyll concentration with high levels of chlorophyll in subarctic Pacific Ocean, North Atlantic 
Geosci. Model Dev. Discuss., https://doi.org/10.5194/gmd-2018-68

Manuscript under review for journal Geosci. Model Dev.

Discussion started: 2 May 2018

(c) Author(s) 2018. CC BY 4.0 License.

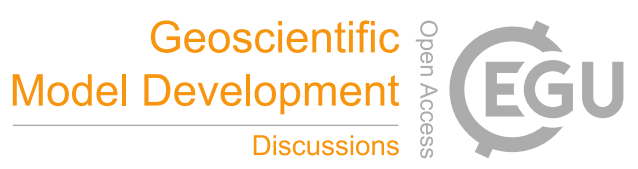

Ocean, equatorial Pacific, and low levels of chlorophyll in subtropical ocean. NESM-2.0.1 simulates relatively higher chlorophyll concentration along the extratropical (except Arctic) coastal regions, but compared to observations, the model generally underestimates chlorophyll concentration at the tropical coastal regions, especially over the tropical Indian Ocean and Atlantic Ocean. This underestimation is probably associated with the deficiencies in modeled coastal dynamics, which is usually not represented well by the relatively coarse resolution global ocean models (Aumont et al., 2015). It is reported that the observed chlorophyll distribution is better reproduced when PISCES is coupled to a higher resolution ocean circulation model (Lee et al., 2000; Hood et al., 2003; Kone et al., 2009). In the Southern Ocean where the seawater is typically characterized by high nutrients and low chlorophyll (Lin et al., 2016), the model apparently overestimates chlorophyll concentration when compared with satellite-derived observations. Previous studies pointed out that chlorophyll concentrations derived from reflectance by standard algorithms tend to be underestimated by a factor of about 2 to 2.5 , especially in intermediate concentrations regions such as the Southern Ocean (Garcia et al., 2005; Kahru and Mitchell, 2010). Therefore, the overestimate of chlorophyll concentration by NESM-2.0.1 in the Southern Ocean may partly be explained by the underestimates of satellite-derived chlorophyll.

Net primary production (NPP) of phytoplankton in NESM-2.0.1 is calculated as a function of nutrient availability, ocean temperature, and photosynthetic available radiation (PAR), which is associated with distribution of chlorophyll. Here we compare modeled NPP with data-based estimate that is calculated as a function of sea surface temperature, PAR, and satelliteobserved chlorophyll concentrations (Fig. 4). The large-scale distribution of relatively high NPP in the central-eastern Pacific, subarctic Pacific, and North Atlantic is well reproduced by NESM-2.0.1. Major discrepancies are seen in the central-eastern Pacific, northern North Atlantic and Arctic coastal regions. The overestimated NPP in the equatorial central-eastern Pacific is probably related to the model's bias in simulation of the Pacific cold tongue, which was shifted westward with overestimated intensity (Cao et al., 2015). NPP are underestimated in the northern North Atlantic, Arabian Sea, subarctic North Pacific and Arctic coastal regions, which is likely related to the model's underestimation of veridical mixing and coastal upwelling. Averaged over 1990s, globally integrated ocean NPP from NESM-2.0.1 simulation is $41.5 \mathrm{PgC} \mathrm{yr}^{-1}$, compared with data-based estimate of 37 to $67 \mathrm{PgC} \mathrm{yr}^{-1}$. The large range of data-based estimate of global NPP is a result of different satellite observations and different algorithms for the NPP estimation (Longhurst et al., 1995; Antoine et al., 1996; Behrenfeld and Falkowski, 1997b; Behrenfeld et al., 2005). Global NPP simulated by CMIP5 models also show a wide range of values from 30.9 to $78.7 \mathrm{PgC} \mathrm{yr}^{-}$ ${ }^{1}$ (Bopp et al., 2013). NESM-2.0.1 simulated values of global NPP is therefore within the range of data-based estimates and current model simulations. Of the NESM-2.0.1 simulated global ocean NPP, $19 \%$ is contributed from diatoms, and $81 \%$ is contributed from nanoplankton. For comparison, the data-based estimate of NPP associated with diatoms accounts for $7 \%$ to $32 \%$ of the total NPP (Uitz et al.,2010; Hirata et al., 2011), and ocean biogeochemical models estimates that $15 \%$ to $30 \%$ global NPP is from diatoms (Aumont et al., 2003; Dutkiewicz et al., 2005; Yool and Popova, 2011).

Spatial resolution of the oceanic component of NESM-2.0.1 is relatively coarse, especially in high latitudes. It is reported that an ocean model with higher spatial resolution would produce a larger NPP as mesoscale and submesoscale processes would significantly enhance ocean biological productivity (McGillicuddy et al., 1998; Oschlies and Garçon, 1998; Lévy et al., 2001). 
Geosci. Model Dev. Discuss., https://doi.org/10.5194/gmd-2018-68

Manuscript under review for journal Geosci. Model Dev.

Discussion started: 2 May 2018

(c) Author(s) 2018. CC BY 4.0 License.

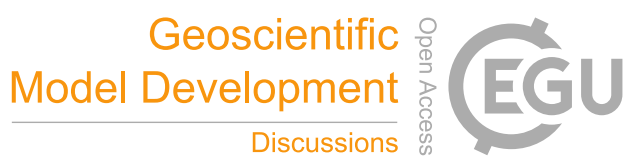

(c) (i)

Also, coastal regions would also be better presented in a higher resolution model. Therefore, it is possible that an ocean model with higher spatial resolution would simulate a higher NPP than what is presented here.

\subsection{Evaluation of NESM-2.0.1 simulated ocean carbon cycle with observations}

Here we compare NESM-2.0.1 simulated air-sea $\mathrm{CO}_{2}$ flux and oceanic uptake of atmospheric $\mathrm{CO}_{2}$ during the historical period against available observations.

We compare model-simulated air-sea $\mathrm{CO}_{2}$ flux against observational-based estimate for the reference year of 2000 (Takahashi et al., 2009). Air-sea $\mathrm{CO}_{2}$ flux in NESM-2.0.1 is calculated following OCMIP protocol that is defined as:

$\mathrm{F}=K_{w} \times S_{A} \times\left(P_{\mathrm{W}}-P_{\mathrm{a}}\right)$

Where $K_{W}$ is the $\mathrm{CO}_{2}$ gas transfer coefficient calculated as a function of wind speed, $S_{A}$ is the solubility of $\mathrm{CO}_{2}$ at the sea

surface, $P_{a}$ and $P_{w}$ are $\mathrm{CO}_{2}$ partial pressure at the overlying atmosphere and sea surface, respectively. Defined in this way, a positive value of $\mathrm{F}$ represents $\mathrm{CO}_{2}$ flux out of the ocean, i.e. from ocean to the atmosphere.

As shown in Fig. 5, NESM-2.0.1 reproduces well observed large-scale pattern of air-sea $\mathrm{CO}_{2}$ flux with $\mathrm{CO}_{2}$ outgassing in the equatorial oceans and $\mathrm{CO}_{2}$ uptake in the mid-to-high latitude oceans. Strong $\mathrm{CO}_{2}$ uptake is observed in the North Atlantic Ocean where sea surface temperature is low and formation of deep water is active, both of which act to absorb $\mathrm{CO}_{2}$ from the atmosphere. It appears that the model overestimates both the amount and extent of $\mathrm{CO}_{2}$ outgassing in the equatorial Pacific Ocean. According to Eq. (1), air-sea $\mathrm{CO}_{2}$ flux is calculated from the combined effects of three factors: surface wind speed, $\mathrm{CO}_{2}$ solubility and partial pressure difference between atmosphere and ocean $\left(\mathrm{dpCO}_{2}\right)$. As expected, the global pattern of airsea $\mathrm{CO}_{2}$ flux is mainly determined by simulated difference in $\mathrm{CO}_{2}$ pressure $\left(\mathrm{dpCO}_{2}\right)$. Simulated bias in wind speed would also contribute to the bias in the air-sea $\mathrm{CO}_{2}$ flux. As pointed out by Cao et al., (2015), wind speed in the equatorial Pacific Ocean is overestimated relative to observations, which would also contribute to the overestimated air-sea $\mathrm{CO}_{2}$ flux in this region.

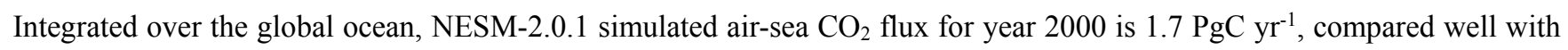
data-based estimates of $1.6 \pm 0.9 \mathrm{PgC} \mathrm{yr}^{-1}$ (Takahashi et al., 2009).

Now we compare model-simulated ocean storage of anthropogenic $\mathrm{CO}_{2}$ during the 1990 s (i.e. cumulative ocean $\mathrm{CO}_{2}$ uptake from pre-industrial time as a result of ocean's uptake of anthropogenic $\mathrm{CO}_{2}$ emissions) with data-based estimates from GLODAP (Key et al., 2004) in terms of both latitude-depth distribution (Fig. 6a, c) and vertically integrated column inventory (Fig. 6b, d). NESM-2.0.1 captures the observed distribution of anthropogenic $\mathrm{CO}_{2}$ in the ocean. As pointed out by Sabine et al., (2004), deep penetrations of anthropogenic $\mathrm{CO}_{2}$ are typically associated with convergence zones at temperate latitudes and high latitude oceans where vertical mixing is strong. For both data-based estimates and model simulations, substantial amount of anthropogenic $\mathrm{CO}_{2}$ has penetrated down to the ocean interior as deep as $1000 \mathrm{~m}$ with two penetration tongues near $40^{\circ} \mathrm{N}$ and $40^{\circ} \mathrm{S}$. In the North Atlantic where deep water forms, substantial amount of anthropogenic $\mathrm{CO}_{2}$ has penetrated down to more than $2000 \mathrm{~m}$ of the ocean. NESM-2.0.1 also captures the observed large-scale pattern of vertically integrated column inventory of anthropogenic $\mathrm{CO}_{2}$ with largest storage in the North Atlantic Ocean. However, the model appears to overestimate 
Geosci. Model Dev. Discuss., https://doi.org/10.5194/gmd-2018-68

Manuscript under review for journal Geosci. Model Dev.

Discussion started: 2 May 2018

(c) Author(s) 2018. CC BY 4.0 License.

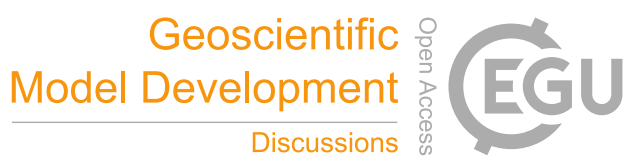

(c) (i)

the carbon storage in the Pacific Ocean at the northern hemisphere.

Globally integrated anthropogenic $\mathrm{CO}_{2}$ from NESM-2.0.1 simulation and observation for the 1990s is $120 \mathrm{PgC}$ and $106 \pm 17$ $\mathrm{PgC}$ (Sabine et al., 2004), respectively. We also calculated the present-day anthropogenic $\mathrm{CO}_{2}$ budget over different periods (1980s, 1990s, 2000s, 2002-2011, and from pre-industrial to 2011) and compared NESM-2.0.1 simulated results against the data-based estimate provided by IPCC AR5 (Table 2). The model-simulated ocean uptake of anthropogenic $\mathrm{CO}_{2}$ is slightly lower than that from IPCC AR5, but within the estimated uncertainty range. For example, from the pre-industrial time to year 2011, NESM-2.0.1 simulated cumulative oceanic $\mathrm{CO}_{2}$ uptake is $144 \mathrm{PgC}$, compared with data-based estimates of $155 \pm 30$ $\mathrm{PgC}$.

Figure 7 compares spatial pattern of NESM-2.0.1 simulated carbon-related fields with corresponding observations using Taylor diagrams (Taylor, 2001). As shown in Fig. 7, model-simulated statistic pattern of surface nitrite and phosphate compares well with observations with correlation coefficients $r>0.9$ and normalized standardized deviation (SD) close to 1.0. However, simulated spatial pattern of surface silicate shows larger deviations from the observation. Simulated spatial pattern of chlorophyll and NPP compares poorly with observations with a correlation of 0.45 and 0.40 , respectively. Simulated spatial pattern of air-sea $\mathrm{CO}_{2}$ flux shows good agreement with observations with a correlation coefficient of 0.75 and a normalized $\mathrm{SD}$ close to 1 . It is noted that chlorophyll, NPP and air-sea $\mathrm{CO}_{2}$ flux is not directly observed but diagnosed from observationalbased data, and there is considerable uncertainty associated with the data.

In short, NESM-2.0.1 reproduces reasonably well the large-scale features of marine biogeochemical fields, including nutrients, chlorophyll, NPP, air-sea $\mathrm{CO}_{2}$ flux, and anthropogenic carbon storage, indicating that the model can be used as a useful tool to investigate the response of the ocean carbon cycle to changes in atmospheric $\mathrm{CO}_{2}$ and global climate.

\subsection{Response of the ocean $\mathrm{CO}_{2}$ uptake to atmospheric $\mathrm{CO}_{2}$ and global warming}

In this section, we first present NESM-2.0.1 simulated physical climate change and oceanic $\mathrm{CO}_{2}$ uptake under the prescribed atmospheric $\mathrm{CO}_{2}$ concentration pathway of RCP 8.5 scenario. We then present NESM-2.0.1 simulated oceanic $\mathrm{CO}_{2}$ uptake in the benchmark simulations with $1 \%$ per year increase in atmospheric $\mathrm{CO}_{2}$.

\subsubsection{NESM-2.0.1 simulated physical climate change under RCP 8.5}

25 In this section, we investigate NESM-2.0.1 simulated oceanic $\mathrm{CO}_{2}$ uptake in response to increasing atmospheric $\mathrm{CO}_{2}$ concentration and $\mathrm{CO}_{2}$-induced climate change. Increasing atmospheric $\mathrm{CO}_{2}$ directly affects air-sea $\mathrm{CO}_{2}$ flux and thus oceanic $\mathrm{CO}_{2}$ uptake. Meanwhile, $\mathrm{CO}_{2}$-induced warming also affects the ocean carbon cycle via changes in climate fields such as temperature, ocean stratification, and ocean circulation. Previous studies proposed that the response of the ocean carbon uptake can be approximated as a linear sum of two parts: 1) the response to changes in atmospheric $\mathrm{CO}_{2}$ concentration (carbonconcentration feedback), and 2) the response to changes in surface temperature (carbon-climate feedback) (Friedlingstein et al., 2006; Arora et al., 2013).

To investigate carbon-concentration feedback and carbon-climate feedback and the nonlinear interactions between the two, we 
Geosci. Model Dev. Discuss., https://doi.org/10.5194/gmd-2018-68

Manuscript under review for journal Geosci. Model Dev.

Discussion started: 2 May 2018

(c) Author(s) 2018. CC BY 4.0 License.

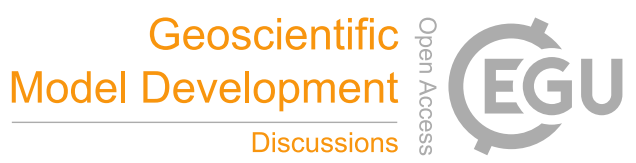

(c) (i)

use the NESM-2.0.1 to perform three sensitivity simulations: biogeochemically-coupled (BC), radiatively-coupled (RC) and fully-coupled (FC). The detailed setup of these experiments were described in Section 2 and listed in Table 1.

Figure 8 shows NESM-2.0.1 simulated changes (relative to pre-industrial level) in global annual mean surface air temperature (SAT), mixed layer depth (MLD), and the intensity of Atlantic meridional overturning circulation (AMOC) at $30^{\circ} \mathrm{N}$ from 1900 to 2100 under RCP8.5 scenario. As expected, substantial change of SAT, MLD and AMOC intensity is observed in FC and RC simulation where increasing atmospheric $\mathrm{CO}_{2}$ is allowed to affect atmospheric radiative transfer. No significant long-term trend is observed in $\mathrm{BC}$ simulation where increasing atmospheric $\mathrm{CO}_{2}$ is only allowed to affect the ocean carbon cycle. NESM2.0.1 simulated annual mean SAT anomalies over the period of 2080 to 2100 (relative the period of 1986-2005) is 4.0K, which

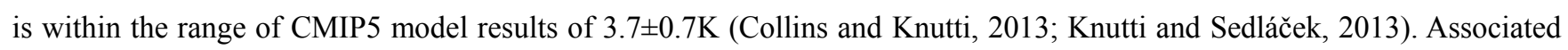
with increasing atmospheric temperature, global ocean also becomes warmer in $\mathrm{FC}$ and $\mathrm{RC}$ simulations, reducing $\mathrm{CO}_{2}$ solubility in seawater and acting to reduce oceanic $\mathrm{CO}_{2}$ uptake.

MLD and AMOC show much stronger interannual fluctuation than SAT, but both of them show long-term trend of decrease. The reduction of mixed layer depth, which is associated with a relatively faster warming of the surface ocean and a slower response of the deep ocean, indicates a more stabilized upper ocean with global warming (Held et al., 2010). The pre-industrial value of the NESM-2.0.1 simulated AMOC index is $24 \mathrm{~Sv}\left(1 \mathrm{~Sv}=10^{6} \mathrm{~m}^{3} \mathrm{~s}^{-1}\right)$, compared with the value of 14 to $31 \mathrm{~Sv}$ from CMIP5 models (Weaver et al., 2012). The modeled annual mean of AMOC transport at $26^{\circ} \mathrm{N}$ averaged from 2000 to 2004 is $25 \mathrm{~Sv}$ while the observation record from RAPID/MOCHA (Rapid Climate Change programme / Meridional Ocean Circulation and Heatflux Array) is $17.5 \pm 3.8 \mathrm{~Sv}$ during 2004 to 2011 (Rhein et al., 2013). A substantial weakening of AMOC intensity in the RC and FC simulations is observed in 21th century under the RCP8.5 scenario, which is associated with ocean surface warming and increased freshwater input at the North Atlantic (Gregory et al., 2005). By 2100, the simulated intensity of AMOC declines to about half of its pre-industrial value. The simulated 54\% weakening of AMOC by the end of this century is at the higher end of what are simulated by CMIP5 models that range from $15 \%$ to $60 \%$ under the RCP 8.5 scenario (Cheng et al., 2013).

\subsubsection{NESM-2.0.1 simulated oceanic $\mathrm{CO}_{2}$ uptake under RCP 8.5}

Changes in the ocean carbon cycle are tightly associated with the change in physical climate processes (Doney et al., 2004). In the FC simulation, weakening of ocean vertical mixing, as indicated by the reduced mixed layer depth and weakening of AMOC, will reduce the vertical exchange of $\mathrm{CO}_{2}$ between the upper ocean and the ocean interior, and thus suppress oceanic $\mathrm{CO}_{2}$ uptake. A warmer surface ocean would reduce $\mathrm{CO}_{2}$ solubility, also suppressing oceanic $\mathrm{CO}_{2}$ uptake.

Figure 9 shows time evolution of model-simulated oceanic $\mathrm{CO}_{2}$ uptake for the simulations of $\mathrm{BC}$ (biogeochemical coupled),

RC (radiative coupled), FC (fully coupled), and the linear sum of BC and RC. In BC simulation, only increasing atmospheric $\mathrm{CO}_{2}$ affects the ocean carbon cycle. By year 2100, the modeled global ocean has absorbed a total of $604 \mathrm{PgC}$ anthropogenic $\mathrm{CO}_{2}$ from the atmosphere. In $\mathrm{RC}$ simulation, constant atmospheric $\mathrm{CO}_{2}$ is seen by the ocean carbon cycle, and the atmosphere 
Geosci. Model Dev. Discuss., https://doi.org/10.5194/gmd-2018-68

Manuscript under review for journal Geosci. Model Dev.

Discussion started: 2 May 2018

(c) Author(s) 2018. CC BY 4.0 License.

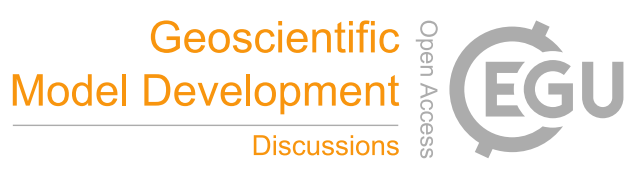

radiation sees increasing atmospheric $\mathrm{CO}_{2}$ concentration. As discussed above, increasing sea surface temperature, increasing ocean stratification, and reduced $\mathrm{AMOC}$ all act to decrease $\mathrm{CO}_{2}$ uptake. As a result, $\mathrm{CO}_{2}$-induced warming alone causes the ocean to release $\mathrm{CO}_{2}$ to the atmosphere (negative $\mathrm{CO}_{2}$ uptake). By year 2100, modeled cumulative $\mathrm{CO}_{2}$ uptake is $-37.6 \mathrm{PgC}$. In $\mathrm{FC}$ simulation, oceanic $\mathrm{CO}_{2}$ uptake is affected by both of the increase in atmospheric $\mathrm{CO}_{2}$ and $\mathrm{CO}_{2}$-induced global warming. By the end of 21th century, the NESM-2.0.1 simulated cumulative oceanic $\mathrm{CO}_{2}$ uptake in the FC run is $516 \mathrm{PgC}$, which is close to the middle value of $\sim 500 \mathrm{PgC}$ from CMIP5 models under the same RCP 8.5 scenario (Jones et al., 2013).

As seen from Figure 9, the sum of the simulated oceanic $\mathrm{CO}_{2}$ uptake from the $\mathrm{BC}$ and $\mathrm{RC}$ simulations (566 $\mathrm{PgC}$ ) is larger than that from the $\mathrm{FC}$ run $\left(516 \mathrm{PgC}\right.$ ), indicating that the biogeochemical effect of atmospheric $\mathrm{CO}_{2}$ (carbon-concentration feedback) and radiative effect of atmospheric $\mathrm{CO}_{2}$ (carbon-climate feedback) on oceanic $\mathrm{CO}_{2}$ uptake is not exactly additive. This nonlinearity has also been found in previous studies (Boer and Arora, 2009; Gregory et al., 2009; Schwinger et al., 2014). The NESM-2.0.1 simulated nonlinearity (discrepancy between the sum of biogeochemical and radiative effect on ocean carbon uptake and the total carbon uptake, i.e. BC+RC-FC) is $50.4 \mathrm{PgC}$ by the end of 21 th century. This nonlinearity is about $9.8 \%$ of the total ocean uptake, and the magnitude of the nonlinearity $(50.4 \mathrm{PgC})$ is comparable to the magnitude of the radiative effect on ocean carbon uptake (-37.6 PgC).

To better understand oceanic $\mathrm{CO}_{2}$ uptake in response to changing atmospheric $\mathrm{CO}_{2}$ and $\mathrm{CO}_{2}$-induced climate change, Figure 10 shows the spatial distribution of anthropogenic air-sea $\mathrm{CO}_{2}$ flux at the end of 21th century (averaged over year 2091 to 2100) under the RCP8.5 scenario for FC, RC, and BC simulations, respectively. Also shown is the difference between FC and the sum of $\mathrm{RC}$ and $\mathrm{BC}$. Positive values represent $\mathrm{CO}_{2}$ flux out of ocean, and negative values represent $\mathrm{CO}_{2}$ flux into the ocean. In the $\mathrm{BC}$ simulation, the ocean absorbs atmospheric $\mathrm{CO}_{2}$ in most regions except for a few scattered grid points of Pacific Ocean at middle latitude with slightly $\mathrm{CO}_{2}$ outgassing. The strongest $\mathrm{CO}_{2}$ uptake is observed in the North Atlantic and Southern Ocean. Results from RC simulation show $\mathrm{CO}_{2}$ outgassing in large parts of the global ocean as a result of $\mathrm{CO}_{2}$-induced warming that reduces $\mathrm{CO}_{2}$ solubility and the rate of $\mathrm{CO}_{2}$ transport from the surface to deep ocean. In the Arctic Ocean, warming induces a net uptake of $\mathrm{CO}_{2}$ as a result of reduced sea ice extend under global warming, which allows more open seawater to absorb atmospheric $\mathrm{CO}_{2}$. FC simulation show the combined effect of increasing atmospheric $\mathrm{CO}_{2}$ and $\mathrm{CO}_{2}$-induced warming on oceanic $\mathrm{CO}_{2}$ uptake (Fig 10c). Positive oceanic $\mathrm{CO}_{2}$ uptake is observed in most regions, indicating the dominant role of $\mathrm{CO}_{2}$ biogeochemical effect in the total oceanic carbon uptake. Similar to the $\mathrm{BC}$ simulation, strongest $\mathrm{CO}_{2}$ uptake is observed in the North Atlantic and Southern Ocean. Somewhat enhanced outgassing is observed in part of subtropical Pacific Ocean where the mixed layer depth is shallow and the water becomes more stratified. Oceanic $\mathrm{CO}_{2}$ uptake in the subtropical Pacific Ocean is small in $\mathrm{BC}$ simulation, and it appears that the radiative effect of atmospheric $\mathrm{CO}_{2}$ is dominant in these regions.

Figure 10d shows the spatial distribution of the difference in air-sea $\mathrm{CO}_{2}$ flux between FC simulation and the sum of $\mathrm{BC}$ and RC simulation. The difference represents the nonlinearity between carbon-climate feedback and carbon-concentration feedback. In NESM, relatively large nonlinearity is observed in the northern North Atlantic Ocean and Southern Ocean (especially the southern South Atlantic), which is consistent with the finding of previous studies (Zickfeld et al., 2011; Schwinger et al., 2014). The nonlinearity can be explained by the interaction between elevated $\mathrm{CO}_{2}$ concentration and climate 
Geosci. Model Dev. Discuss., https://doi.org/10.5194/gmd-2018-68

Manuscript under review for journal Geosci. Model Dev.

Discussion started: 2 May 2018

(c) Author(s) 2018. CC BY 4.0 License.

(c) (i)

change. For example, compared to pre-industrial $\mathrm{CO}_{2}$ background, under elevated $\mathrm{CO}_{2}$ concentrations (RCP 8.5 here), reduced North Atlantic Deep Water (NADW) has a much larger impact on reducing $\mathrm{CO}_{2}$ transport from the surface to deep ocean. Therefore, anthropogenic $\mathrm{CO}_{2}$ uptake in the North Atlantic in the fully coupled simulation (FC) is smaller than the linear sum of the biogeochemically-coupled (BC) and radiatively-coupled (RC) simulations, Also, in the FC simulation, compared with the $\mathrm{RC}$ simulation, more ocean carbon is subject to increasing ocean temperature and therefore ocean warming would have a larger effect on $\mathrm{CO}_{2}$ outgassing compared to the warming effect on top of pre-industrial $\mathrm{CO}_{2}$ state. Thus, the sum of $\mathrm{RC}$ and $\mathrm{BC}$ simulation underestimates $\mathrm{CO}_{2}$ outgassing from the ocean in the $\mathrm{FC}$ simulation.

\subsection{3 carbon-concentration and carbon-climate feedback diagnosed from NESM-2.0.1}

We further investigate the carbon-concentration and carbon-climate feedback. Friedlingstein (2006) proposed that cumulative oceanic $\mathrm{CO}_{2}$ uptake can be decomposed approximately using the linear sum of carbon-concentration feedback and carbon-climate feedback:

$\int_{0}^{t} F^{\prime} d t \approx \gamma \Delta T+\beta \Delta C_{A}$

Where $F^{\prime}$ is the air-sea $\mathrm{CO}_{2}$ flux change and $\int_{0}^{t} F^{\prime} d t$ represent the cumulated ocean carbon uptake. $\gamma$ represents the sensitivity of ocean carbon storage to climate change and $\Delta T$ is the change in global mean surface air temperature. $\beta$ represents the sensitivity of ocean carbon storage to the change in atmospheric $\mathrm{CO}_{2}$ concentration and $\Delta C_{A}$ is the atmospheric $\mathrm{CO}_{2}$ concentration change.

Arora et al., (2013) obtained these two parameters following equation (2) with different sensitive experiments, i.e. biogeochemically-coupled simulations and radiatively-coupled simulations, and diagnosed these two coefficients using CMIP5 model outputs. In the biogeochemically-coupled simulations where the ocean carbon uptake is only affected by changing atmospheric $\mathrm{CO}_{2}$, Eq. (2) can be simplified as:

$\int_{0}^{t} F^{\prime} d t \approx \beta \Delta C_{A}$

where F' represent air-sea $\mathrm{CO}_{2}$ flux change in the biogeochemically coupled simulation. In the radiatively-coupled simulations where the ocean carbon uptake is only affected by changing climate, Eq. (2) can be simplified as:

$\int_{0}^{t} F^{\prime} d t \approx \gamma \Delta T$

where $\mathrm{F}$ ' represent air-sea $\mathrm{CO}_{2}$ flux change in the radiatively coupled simulation.

In this study, we estimate the strength of carbon-concentration and carbon-climate feedback following Arora et al., (2013) using equations (3) and (4). Figure 11 shows the change in ocean carbon storage as a function of change in and atmospheric $\mathrm{CO}_{2}$ (Fig. 11a) and global annual mean surface temperature (Fig. 11b), respectively. The derived evolution of carbonconcentration feedback parameter $\beta$ as a function of atmospheric $\mathrm{CO}_{2}$ concentration and carbon-climate feedback parameter $\gamma$ as a function of change in temperature is shown in Fig. 11c and 11d, respectively.

As shown in Fig. 11, in the $\mathrm{BC}$ simulation modeled ocean storage of anthropogenic $\mathrm{CO}_{2}$ scales roughly linearly with atmospheric $\mathrm{CO}_{2}$, and in the $\mathrm{RC}$ simulation modeled ocean storage of anthropogenic $\mathrm{CO}_{2}$ scales roughly linearly with 
Geosci. Model Dev. Discuss., https://doi.org/10.5194/gmd-2018-68

Manuscript under review for journal Geosci. Model Dev.

Discussion started: 2 May 2018

(c) Author(s) 2018. CC BY 4.0 License.

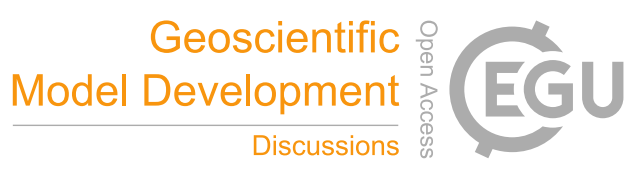

(c) (i)

changes in global mean surface temperature. Increasing atmospheric $\mathrm{CO}_{2}$ alone increases oceanic $\mathrm{CO}_{2}$ uptake whereas increasing temperature alone decreases $\mathrm{CO}_{2}$ uptake. Therefore, carbon-climate parameter $\gamma$ is negative while carbonconcentration parameter $\beta$ is positive (Fig. 11). After an initial adjustment period, a decreasing trend of $\gamma$ is observed, which reaches to the value of $-6.2 \mathrm{PgC}$ per $\mathrm{K}$ at the end of 21 th century. The decreasing trend of $\gamma$ (more negative) indicates that with enhanced warming, one degree of surface temperature increase would induce more $\mathrm{CO}_{2}$ outgassing form the ocean (Fig 11d). The parameter $\beta$ initially increases with atmospheric $\mathrm{CO}_{2}$, and then slightly decreases (Fig. 11c) with the value of 0.83 $\mathrm{PgC} / \mathrm{ppm}$ at the year 2100. The decreasing trend of $\beta$ is consistent with the slowdown of the increasing trend of $\mathrm{CO}_{2}$ flux at the end of 21 th century. Similar trends of carbon-climate feedback parameter and carbon-concentration feedback parameter are also found in the previous research (Arora et al., 2013). The increased sensitivity of $\mathrm{CO}_{2}$ outgassing to increasing temperature and decreased sensitivity of $\mathrm{CO}_{2}$ uptake to increasing atmospheric $\mathrm{CO}_{2}$ indicate that for a given amount of $\mathrm{CO}_{2}$ emission, a larger fraction of anthropogenic $\mathrm{CO}_{2}$ would remain in the atmosphere.

\subsection{4 carbon-concentration and carbon-climate feedback parameters from $1 \%$ per year $\mathrm{CO}_{2}$ simulations}

Arora et al., (2013) analyzed carbon-concentration and carbon-climate feedback parameters from CMIP5 models using the benchmark simulations in which atmospheric $\mathrm{CO}_{2}$ is assumed to increase at a rate of $1 \%$ per year for 140 years to reach $4 \times$ $\mathrm{CO}_{2}$. To have a direct comparison with CMIP5 results, we performed another set of simulations under the same $\mathrm{CO}_{2}$ concentration pathway.

Figure 12 shows time evolution of model-simulated oceanic $\mathrm{CO}_{2}$ uptake for the simulations of $\mathrm{BC}, \mathrm{RC}, \mathrm{FC}$, and the linear sum of $\mathrm{BC}$ and $\mathrm{RC}$ in $1 \%$ per year $\mathrm{CO}_{2}$ increase experiments. To some extent, Figure 12 shows similar results with time evolution of model-simulated oceanic $\mathrm{CO}_{2}$ uptake under RCP 8.5 scenario as shown in Figure 9. By year 140, largest positive oceanic $\mathrm{CO}_{2}$ uptake $(685 \mathrm{PgC})$ is observed in $\mathrm{BC}$ simulation while relative small negative oceanic uptake $(-36 \mathrm{PgC})$ is seen in $\mathrm{RC}$ simulation, and the sum of the oceanic $\mathrm{CO}_{2}$ uptake from the $\mathrm{BC}$ and $\mathrm{RC}$ simulations (649 $\mathrm{PgC}$ ) is larger than that from the $\mathrm{FC}$ run (592 $\mathrm{PgC}$ ). It is reported that the nonlinearity between biogeochemical and radiative feedback accounts for 3.6\% $-10.6 \%$ of the total ocean carbon uptake for CMIP5 models in $1 \%$ per year $\mathrm{CO}_{2}$ increase experiments (Schwinger et al., 2014). For comparison, at the end of $1 \%$ per year $\mathrm{CO}_{2}$ increase simulations, NESM-2.0.1 simulated nonlinearity is $9.6 \%(57 \mathrm{PgC})$ of the total oceanic $\mathrm{CO}_{2}$ uptake, which is comparable with the relative magnitude of the nonlinearity estimated by CMIP5 models. The comparison of feedback parameters is provided in Fig. 13. At the end of $1 \%$ increasing $\mathrm{CO}_{2}$ simulation, the diagnosed value of $\beta$ from CMIP5 models ranges from 0.69 to $0.91 \mathrm{PgC} / \mathrm{ppm}$ with a multi-model mean value of $0.80 \mathrm{PgC} / \mathrm{ppm}$. For comparison, the carbon-concentration feedback parameter diagnosed from NESM-2.0.1 simulations with 1\% per year increase in atmospheric $\mathrm{CO}_{2}$ is $0.81 \mathrm{PgC} / \mathrm{ppm}$ at the end of simulation. Compared to the carbon-concentration feedback parameter, model-simulated carbon-climate feedback parameter has a much larger range among CMIP5 models with the values ranging from -2.4 to $-12.1 \mathrm{PgC} / \mathrm{K}$ at the end of simulation. The larger model-dependence of carbon-climate feedback parameter is expected given the large uncertainty in model-simulated climate change and dependence of carbon cycle processes on climate 
Geosci. Model Dev. Discuss., https://doi.org/10.5194/gmd-2018-68

Manuscript under review for journal Geosci. Model Dev.

Discussion started: 2 May 2018

(c) Author(s) 2018. CC BY 4.0 License.

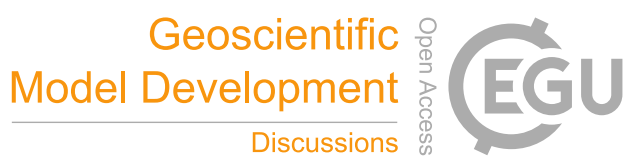

(c) (i)

change. The mean value of carbon-climate feedback parameter from CMIP5 models is $-7.8 \mathrm{PgC} / \mathrm{K}$. For comparison, at the end of simulation, the NESM-2.0.1 simulated value of carbon-climate parameter $\gamma$ with the scenario of $1 \%$ per year increase in atmospheric $\mathrm{CO}_{2}$ is $-7.1 \mathrm{PgC} / \mathrm{K}$. These results indicate that $\mathrm{NESM}-2.0 .1$ simulated response of oceanic $\mathrm{CO}_{2}$ uptake to atmospheric $\mathrm{CO}_{2}$ and climate change is in general agreement with ensemble means of the CMIP5 models.

\section{Conclusion and discussion}

In this study, we evaluated the performance of the NUIST Earth System Model (NESM) in simulating the present-day ocean carbon cycle. We also investigated the model-simulated oceanic $\mathrm{CO}_{2}$ uptake in terms of the oceanic $\mathrm{CO}_{2}$ uptake in response to increasing atmospheric $\mathrm{CO}_{2}$ alone, e.g., carbon-concentration feedback, and the oceanic $\mathrm{CO}_{2}$ uptake in response to $\mathrm{CO}_{2-}^{-}$ induced climate change alone, e.g., carbon-climate feedback.

The model simulates reasonably well the large-scale patterns of surface nutrient concentration including nitrate, phosphate, and silicate. The model also does a reasonable job in simulating large-scale distribution of chlorophyll and ocean net primary

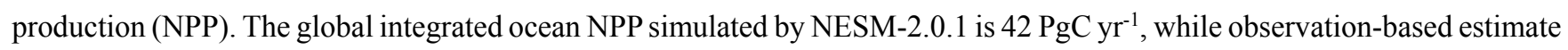

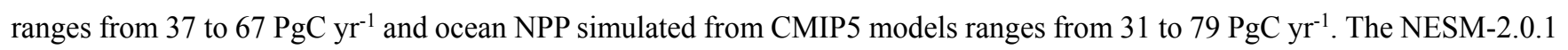
simulated cumulative anthropogenic $\mathrm{CO}_{2}$ uptake from the pre-industrial time to year 2011 is $144 \mathrm{PgC}$, compared well with data-based estimates of $155 \pm 30 \mathrm{PgC}$ (Ciais et al., 2013).

As proposed by Friedlingstein et al. (2006), the response of oceanic $\mathrm{CO}_{2}$ uptake can be decomposed by the sum of two components, the response to increasing atmospheric $\mathrm{CO}_{2}$ alone (carbon-concentration feedback) and the response to $\mathrm{CO}_{2}$ induced climate change alone (carbon-climate feedback): In the simulation where atmospheric $\mathrm{CO}_{2}$ increases by $1 \%$ per year, by year 140, the NESM-2.0.1 simulated carbon-concentration feedback parameter is $0.81 \mathrm{PgC} / \mathrm{ppm}$ and carbon-climate feedback parameter is $-7.1 \mathrm{PgC} / \mathrm{K}$, indicating that increasing atmospheric $\mathrm{CO}_{2}$ alone increases oceanic $\mathrm{CO}_{2}$ uptake while global warming alone decreases oceanic $\mathrm{CO}_{2}$ uptake. These estimated feedback parameters are in general agreement with those estimated by CMIP5 models that yield carbon-concentration feedback parameters ranging from 0.69 to $0.91 \mathrm{PgC} / \mathrm{ppm}$ and carbon-climate feedback parameters ranging from -2.4 to $-12.1 \mathrm{PgC} / \mathrm{K}$. These results indicate that the NESM-2.0.1 simulated response of oceanic $\mathrm{CO}_{2}$ uptake to increasing atmospheric $\mathrm{CO}_{2}$ and climate change are in general agreement with the state-ofthe-art Earth system models.

It is also found from NESM-2.0.1 simulations that the sum of oceanic $\mathrm{CO}_{2}$ uptake in response to changes in atmospheric $\mathrm{CO}_{2}$ alone and climate changes alone is somewhat larger than the oceanic $\mathrm{CO}_{2}$ uptake in response to the combined effect of atmospheric $\mathrm{CO}_{2}$ concentration and $\mathrm{CO}_{2}$-induced climate change. The difference between the total oceanic $\mathrm{CO}_{2}$ uptake and the linear sum of carbon-concentration feedback and carbon-climate feedback indicates the nonlinearity between these two feedbacks. In the NESM-2.0.1 simulation with $1 \%$ per year increase in atmospheric $\mathrm{CO}_{2}$, by year 140 , the nonlinearity is $9.6 \%$ of the total oceanic $\mathrm{CO}_{2}$ uptake. For comparison, nonlinearity between the carbon-concentration and carbon-climate feedback from CMIP5 models accounts for $3.6 \%$ to $10.6 \%$ of the total oceanic $\mathrm{CO}_{2}$ uptake. 
Geosci. Model Dev. Discuss., https://doi.org/10.5194/gmd-2018-68

Manuscript under review for journal Geosci. Model Dev.

Discussion started: 2 May 2018

(c) Author(s) 2018. CC BY 4.0 License.

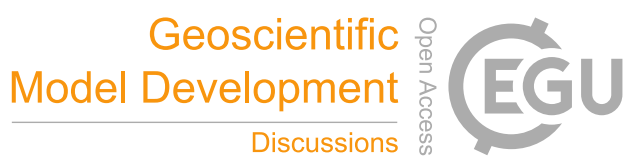

(c) (i)

While the results presented here show some success of the NESM-2.0.1 model in the simulation of processes involving the ocean ecosystem and ocean $\mathrm{CO}_{2}$ uptake, the model simulation shows a number of caveats that requires better understanding of the source of the deficiencies and calls for future improvements. In particular, it is not well understood (a) why in the equatorial Pacific the simulated surface silicate concentrations are much higher than the observation, but the surface phosphate concentration is lower than the observation (Fig. 1), (b) why the model captures well the vertical distribution of silicate, but not the nitrate and phosphate concentrations (Fig. 2), and (c) why the model simulates chlorophyll concentration well along the extratropical coastal regions, but not along the tropical coastal regions (Fig. 3). The simulated annual mean distribution of vertical integrated NPP has notorious errors (Fig. 4). Both the simulated NPP and air-sea $\mathrm{CO}_{2}$ flux have large biases in the equatorial Pacific (Fig. 4 and 5), which are likely associated with the model's bias in simulated SST and upwelling fields. These simulated biases are likely to be associated with the climatological bias in simulation of the Pacific cold tongue. The simulated cold tongue shifted westward compared with observations (Cao et al., 2015), implying that the upwelling also shifted westward (Jin 1996; Li and Xie 2014), which may lead to deficiencies in nutrients distribution, NPP and air-sea CO2 flux. This suggests that overcoming of the mean climatological cold tongue bias should be a major target in further improvement of the oceanic carbon cycle simulation.

In the future, the NESM, together with its ocean carbon cycle component, will be continuously developed and improved. To better evaluate the NESM-2.0.1 simulated ocean dynamics and the ocean carbon cycle, the simulation of natural and bomb ${ }^{14} \mathrm{C}$ will be implemented because their distributions in the ocean is a good indicator of the strength of ocean mixing and deep ocean circulation (Levin and Vago, 2000; Matsumoto 2007; Skinner et al, 2017). Also, the model appears to underestimate the concentration of chlorophyll and NPP in the tropical coastal regions as a result of relatively low model resolution, which cannot capture well coastal processes. The development of a higher-resolution $(\sim 10 \mathrm{~km})$ NESM-2.0.1 is planned in the near future, which could better capture the mesoscale processes and coastal dynamics (Griffies et al. 2015). In the future, the NESM-2.0.1 will be used to conduct a series of studies to better understand interactions between the ocean carbon cycle, atmospheric $\mathrm{CO}_{2}$, and climate change.

\section{Code and data availability.}

The source code of NESM-2.0.1, together with all input data are saved in one compressed file, which can be downloaded from https://doi.org/10.5281/zenodo.1184747 after registration. Also, a user guide describing the installation instructions, driver scripts, and software dependencies also can be found in the repository at the same link. The simulation results illustrated in this study can be made available upon request to the authors.

Author contributions. Yifei Dai and Long Cao designed the experiments. Yifei Dai performed the simulations, analyzed the experiments, and made the figures in coordination with Long Cao. The NUIST ESM team led by Bin Wang provided the code of NESM-2.0.1 used in this study and Bin Wang provided helpful discussions. Yifei Dai, Long Cao, and Bin Wang all contributed to the writing of the manuscript. 
Geosci. Model Dev. Discuss., https://doi.org/10.5194/gmd-2018-68

Manuscript under review for journal Geosci. Model Dev.

Discussion started: 2 May 2018

(c) Author(s) 2018. CC BY 4.0 License.

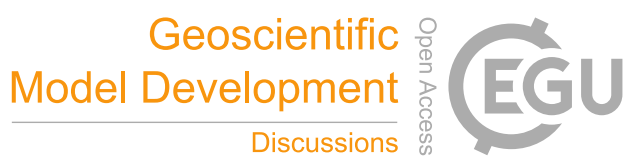

(c) (i)

Acknowledgement. Long Cao is supported by the National Natural Science Foundation of China (41675063; 41422503). Bin

Wang acknowledges the support by the Nanjing University of Information Science and Technology through funding the joint

China-US Atmosphere-Ocean Research Center at the University of Hawaii. Yifei Dai acknowledges the support by the China Scholarship Council by providing a scholarship under the State Scholarship Fund. This is the ESMC publication number XXX and IPRC publication number YYYY.

\section{Reference}

Antoine, D., André, J.M. and Morel, A.: Oceanic primary production: 2. Estimation at global scale from satellite (coastal zone color scanner) chlorophyll. Global biogeochemical cycles, 10(1), 57-69, 1996.

Arora, V.K., Boer, G.J., Friedlingstein, P., Eby, M., Jones, C.D., Christian, J.R., Bonan, G., Bopp, L., Brovkin, V., Cadule, P. and Hajima, T.: Carbon-concentration and carbon-climate feedbacks in CMIP5 Earth system models. Journal of Climate, 26(15), 5289-5314, 2013.

Aumont, O., Maier-Reimer, E., Blain, S. and Monfray, P.: An ecosystem model of the global ocean including Fe, Si, P colimitations. Global Biogeochemical Cycles, 17(2), 1060, 2003.

Aumont, O., Éthé, C., Tagliabue, A., Bopp, L. and Gehlen, M.: PISCES-v2: an ocean biogeochemical model for carbon and ecosystem studies. Geoscientific Model Development, 8(8), 2465-2513, 2015.

Ballantyne, A.P., Alden, C.B., Miller, J.B., Tans, P.P. and White, J.W.C.: Increase in observed net carbon dioxide uptake by land and oceans during the past 50 years. Nature, 488(7409), 70-72, 2012.

Behrenfeld, M.J. and Falkowski, P.G.: Photosynthetic rates derived from satellite-based chlorophyll concentration. Limnology and oceanography, 42(1), 1-20, 1997a.

Behrenfeld M J, Falkowski P G.: A consumer's guide to phytoplankton primary productivity models. Limnology and Oceanography, 42(7), 1479-1491, 1997b.

Behrenfeld, M.J., Boss, E., Siegel, D.A. and Shea, D.M.: Carbon-based ocean productivity and phytoplankton physiology from space. Global biogeochemical cycles, 19, GB1006, 2005.

Boer, G.J. and Arora, V.: Temperature and concentration feedbacks in the carbon cycle. Geophysical Research Letters, 36, L02704, 2009.

Bopp, L., Aumont, O., Cadule, P., Alvain, S. and Gehlen, M.: Response of diatoms distribution to global warming and potential implications: A global model study. Geophysical Research Letters, 32, L19606, 2005.

Bopp, L., Resplandy, L., Orr, J.C., Doney, S.C., Dunne, J.P., Gehlen, M., Halloran, P., Heinze, C., Ilyina, T., Seferian, R. and Tjiputra, J.: Multiple stressors of ocean ecosystems in the 21st century: projections with CMIP5 models. Biogeosciences, 10, 6225-6245, 2013.

Bretherton, F. P.: Earth system science and remote sensing, P. IEEE, 73, 1118-1127, 1985.

Cao, J., Wang, B., Xiang, B., Li, J., Wu, T., Fu, X., Wu, L. and Min, J.: Major modes of short-term climate variability in the 
Geosci. Model Dev. Discuss., https://doi.org/10.5194/gmd-2018-68

Manuscript under review for journal Geosci. Model Dev.

Discussion started: 2 May 2018

(c) Author(s) 2018. CC BY 4.0 License.

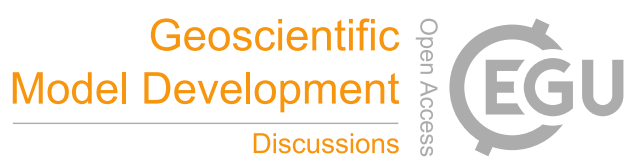

(c) (i)

newly developed NUIST Earth System Model (NESM). Advances in Atmospheric Sciences, 32(5), 585-600, 2015.

Ciais, P., C. Sabine, G. Bala, L. Bopp, V. Brovkin, J. Canadell, A. Chhabra, R. DeFries, J. Galloway, M. Heimann, C. Jones,

C. Le Quéré, R.B. Myneni, S. Piao and P. Thornton.: Carbon and Other Biogeochemical Cycles. In: Cli־mate Change 2013: The Physical Science Basis. Contribution of Working Group I to the Fifth Assessment Report of the

Intergovernmental Panel on Climate Change [Stocker, T.F., D. Qin, G.-K. Plattner, M. Tignor, S.K. Allen, J. Boschung, A. Nauels, Y. Xia, V. Bex and P.M. Midgley (eds.)]. Cambridge University Press, Cambridge, United Kingdom and New York, NY, USA, 2013.

Collins, M., and Coauthors.: Long-term Climate Change: Projections, Commitments and Irreversibility. In: Climate Change 2013: The Physical Science Basis. Contribution of Working Group I to the Fifth Assessment Report of the

Intergovernmental Panel on Climate Change. Stocker, T.F., D. Qin, G.-K. Plattner, et al., Eds., Cambridge University Press, Cambridge, United Kingdom and New York, NY, USA, 2013.

Cox, P.M., Betts, R.A., Jones, C.D., Spall, S.A. and Totterdell, I.J.: Acceleration of global warming due to carbon-cycle feedbacks in a coupled climate model. Nature, 408(6809), 184-187, 2000.

Cheng, W., Chiang, J.C. and Zhang, D.: Atlantic meridional overturning circulation (AMOC) in CMIP5 models: RCP and historical simulations. Journal of Climate, 26(18), 7187-7197, 2013.

Doney, S.C., Lindsay, K., Caldeira, K., Campin, J.M., Drange, H., Dutay, J.C., Follows, M., Gao, Y., Gnanadesikan, A., Gruber, N. and Ishida, A.: Evaluating global ocean carbon models: The importance of realistic physics. Global Biogeochemical Cycles, 18, GB3017, 2004.

Dutkiewicz, S., Follows, M.J. and Parekh, P.: Interactions of the iron and phosphorus cycles: A three-dimensional model study. Global Biogeochemical Cycles, 19, GB1021, 2005.

Friedlingstein, P., Cox, P., Betts, R., Bopp, L., von Bloh, W., Brovkin, V., Cadule, P., Doney, S., Eby, M., Fung, I. and Bala, G.: Climate-carbon cycle feedback analysis: results from the C4MIP model intercomparison. Journal of climate, 19(14), 3337-3353, 2006.

Garcia, C.A.E., Garcia, V.M.T. and McClain, C.R.: Evaluation of SeaWiFS chlorophyll algorithms in the Southwestern Atlantic and Southern Oceans. Remote Sensing of Environment, 95(1), 125-137, 2005.

Garcia, H., Locarnini, R., Boyer, T., Antonov, J., Zweng, M., Baranova, O. and Johnson, D.: World Ocean Atlas 2009, vol. 4, Nutrients (Phosphate, Nitrate, Silicate), edited by: Levitus, S. NOAA Atlas NESDIS, US Gov. Printing Office, Wash., DC, 2010.

Gregory, J.M., Dixon, K.W., Stouffer, R.J., Weaver, A.J., Driesschaert, E., Eby, M., Fichefet, T., Hasumi, H., Hu, A., Jungclaus, J.H. and Kamenkovich, I.V.: A model intercomparison of changes in the Atlantic thermohaline circulation in response to increasing atmospheric $\mathrm{CO}_{2}$ concentration. Geophysical Research Letters, 32, L12703, 2005.

Gregory, J.M., Jones, C.D., Cadule, P. and Friedlingstein, P.: Quantifying carbon cycle feedbacks. Journal of Climate, 22(19), 5232-5250, 2009.

Griffies, Stephen M., and Coauthors.: Impacts on ocean heat from transient mesoscale eddies in a hierarchy of climate 
Geosci. Model Dev. Discuss., https://doi.org/10.5194/gmd-2018-68

Manuscript under review for journal Geosci. Model Dev.

Discussion started: 2 May 2018

(c) Author(s) 2018. CC BY 4.0 License.

(c) (i)

models. Journal of Climate 28(3), 952-977, 2015.

Held, I.M., Winton, M., Takahashi, K., Delworth, T., Zeng, F. and Vallis, G.K.: Probing the fast and slow components of global warming by returning abruptly to preindustrial forcing. Journal of Climate, 23(9), 2418-2427, 2010.

Hirata, T., Hardman-Mountford, N.J., Brewin, R.J.W., Aiken, J., Barlow, R., Suzuki, K., Isada, T., Howell, E., Hashioka, T., Noguchi-Aita, M. and Yamanaka, Y.: Synoptic relationships between surface Chlorophyll-a and diagnostic pigments specific to phytoplankton functional types. Biogeosciences, 8(2), 311-327, 2011.

Hood, R.R., Kohler, K.E., McCreary, J.P. and Smith, S.L.: A four-dimensional validation of a coupled physical-biological model of the Arabian Sea. Deep Sea Research Part II: Topical Studies in Oceanography, 50(22-26), 2917-2945, 2003.

Hunke, E.C., Lipscomb, W.H., Turner, A.K., Jeffery, N. and Elliott, S.: CICE: the Los Alamos Sea Ice Model Documentation and Software User's Manual Version 4.1 LA-CC-06-012. T-3 Fluid Dynamics Group, Los Alamos National Laboratory, Los Alamos N.M, 2010.

Jin, F.F.: Tropical ocean-atmosphere interaction, the Pacific cold tongue, and the El Niño-Southern Oscillation. Science, 274(5284), 76-78, 1996.

Jones, C., Robertson, E., Arora, V., Friedlingstein, P., Shevliakova, E., Bopp, L., Brovkin, V., Hajima, T., Kato, E.,

Kawamiya, M. and Liddicoat, S.: Twenty-first-century compatible $\mathrm{CO}_{2}$ emissions and airborne fraction simulated by CMIP5 earth system models under four representative concentration pathways. Journal of Climate, 26(13), 4398-4413, 2013.

Joos, F. and Spahni, R.: Rates of change in natural and anthropogenic radiative forcing over the past 20,000 years. Proceedings of the National Academy of Sciences, 105(5), 1425-1430, 2008.

Kahru, M. and Mitchell, B.G.: Blending of ocean colour algorithms applied to the Southern Ocean. Remote Sensing Letters, 1(2), 119-124, 2010.

Key, R.M., and Coauthors.: A global ocean carbon climatology: Results from Global Data Analysis Project (GLODAP). Global biogeochemical cycles, 18(4), 357-370, 2004.

Knutti, R. and Sedláček, J.: Robustness and uncertainties in the new CMIP5 climate model projections. Nature Climate Change, 3(4), 369-373, 2013.

Koné, V., Aumont, O., Lévy, M. and Resplandy, L.: Physical and biogeochemical controls of the phytoplankton seasonal cycle in the Indian Ocean: A modeling study. Indian Ocean Biogeochemical Processes and Ecological Variability, 185, 147-166, 2009.

Körtzinger, A., Hedges, J.I. and Quay, P.D.: Redfield ratios revisited: Removing the biasing effect of anthropogenic CO2. Limnology and Oceanography, 46(4), 964-970, 2001.

Larson, J., Jacob, R. and Ong, E.: The model coupling toolkit: a new Fortran90 toolkit for building multiphysics parallel coupled models. The International Journal of High Performance Computing Applications, 19(3), 277-292, 2005.

Le Quéré, C., and Coauthors.: Global carbon budget 2017. Earth System Science Data Discussions, 1-79, 2017.

Lee, C.M., Jones, B.H., Brink, K.H. and Fischer, A.S.: The upper-ocean response to monsoonal forcing in the Arabian Sea: 
Geosci. Model Dev. Discuss., https://doi.org/10.5194/gmd-2018-68

Manuscript under review for journal Geosci. Model Dev.

Discussion started: 2 May 2018

(c) Author(s) 2018. CC BY 4.0 License.

(c) (i)

seasonal and spatial variability. Deep Sea Research Part II: Topical Studies in Oceanography, 47(7-8), 1177-1226, 2000.

Lengaigne, M., Madec, G., Bopp, L., Menkes, C., Aumont, O. and Cadule, P.: Bio-physical feedbacks in the Arctic Ocean using an Earth system model. Geophysical Research Letters, 36, L21602, 2009.

Levin, I. and Hesshaimer, V.: Radiocarbon-a unique tracer of global carbon cycle dynamics. Radiocarbon, 42(1), 69-80, 2000.

Levitus, S., Antonov, J.I., Boyer, T.P. and Stephens, C.: Warming of the world ocean. Science, 287(5461), 2225-2229, 2000.

Lévy, M., Klein, P. and Treguier, A.M.: Impact of sub-mesoscale physics on production and subduction of phytoplankton in an oligotrophic regime. Journal of marine research, 59(4), 535-565, 2001.

Li, G. and Xie, S.P.: Tropical biases in CMIP5 multimodel ensemble: The excessive equatorial Pacific cold tongue and double ITCZ problems. Journal of Climate, 27(4), 1765-1780, 2014.

Li, J., Wang, B. and Yang, Y.M.: Retrospective seasonal prediction of summer monsoon rainfall over West Central and Peninsular India in the past 142 years. Climate Dynamics, 48(7-8), 2581-2596, 2017.

Lin, H., Kuzminov, F.I., Park, J., Lee, S., Falkowski, P.G. and Gorbunov, M.Y.: The fate of photons absorbed by phytoplankton in the global ocean. Science, p.aab2213, 2016.

Longhurst, A., Sathyendranath, S., Platt, T. and Caverhill, C.: An estimate of global primary production in the ocean from satellite radiometer data. Journal of plankton Research, 17(6), 1245-1271, 1995.

Madec, G., and the NEMO team.: NEMO ocean engine. Note du ple de mod'elisation, No 27, Institut Pierre-Simon Laplace (IPSL), France, 2012.

Matsumoto, K.: Radiocarbon-based circulation age of the world oceans. Journal of Geophysical Research: Oceans, 112, C09004, 2007.

McGillicuddy Jr, and Coauthors.: Influence of mesoscale eddies on new production in the Sargasso Sea. Nature, 394(6690), 263-266, 1998.

Menon, S., and Coauthors.: Couplings between changes in the climate system and biogeochemistry (No. LBNL-464E). Ernest Orlando Lawrence Berkeley National Laboratory, Berkeley, CA(US), 2007.

Morel, A. and Berthon, J.F.: Surface pigments, algal biomass profiles, and potential production of the euphotic layer: Relationships reinvestigated in view of remote-sensing applications. Limnology and oceanography, 34(8), 1545-1562, 1989.

Moss, R.H., and Coauthors.: The next generation of scenarios for climate change research and assessment. Nature, 463(7282), 747-756, 2010.

Najjar, R.G.: Marine biogeochemistry, in Climate System Modeling, edited by K.E. Trenberth. Cambridge Univ. Press, New York, 1992.

NOAA ESRL Global Monitoring Division.: Atmospheric Carbon Dioxide Dry Air Mole Fractions from quasi-continuous measurements at Mauna Loa, Hawaii. Compiled by K.W. Thoning, D.R. Kitzis, and A. Crotwell. National Oceanic and Atmospheric Administration (NOAA), Earth System Research Laboratory (ESRL), Global Monitoring Division (GMD): 
Geosci. Model Dev. Discuss., https://doi.org/10.5194/gmd-2018-68

Manuscript under review for journal Geosci. Model Dev.

Discussion started: 2 May 2018

(c) Author(s) 2018. CC BY 4.0 License.

Boulder, Colorado, USA. Version 2017-8, 2016, http://dx.doi.org/10.7289/V54X55RG.

Oschlies, A. and Garçon, V.: Eddy-induced enhancement of primary production in a model of the North Atlantic Ocean, Nature, 394, 266-269, 1998.

Pierce, D.W., and Coauthors.: The fingerprint of human-induced changes in the ocean's salinity and temperature fields. Geophysical Research Letters, 39, L21704, 2012.

Resplandy, L., and Coauthors.: Controlling factors of the oxygen balance in the Arabian Sea's OMZ. Biogeosciences, 9 , 5095-5109, 2012.

Rhein, M., S.R. Rintoul, S. Aoki, E. Campos, D. Chambers, R.A. Feely, S. Gulev, G.C. Johnson, S.A. Josey, A. Kostianoy, C. Mauritzen, D. Roemmich, L.D. Talley and F. Wang. : Observations: Ocean. In: Climate Change 2013: The Physical

Science Basis. Contribution of Working Group I to the Fifth Assessment Report of the Intergovernmental Panel on Climate Change [Stocker, T.F., D. Qin, G.-K. Plattner, M. Tignor, S.K. Allen, J. Boschung, A. Nauels, Y. Xia, V. Bex and P.M. Midgley (eds.)]. Cambridge University Press, Cambridge, United Kingdom and New York, NY, USA, 2013.

Roeckner, E., and Coauthors.: The atmospheric general circulation model ECHAM 5. PART I: Model description. Rep. No. 349, Max-Planck-Institut f'ur Meteorologie, Hamburg, Germany, 2003.

Roesch, A., Wild, M., Gilgen, H. and Ohmura, A.: A new snow cover fraction parameterization for the ECHAM4 GCM .

Clim. Dyn., 17, 933-946, 2001.

Sabine, C.L., and Coauthors.: The oceanic sink for anthropogenic $\mathrm{CO}_{2}$. Science, 305(5682), 367-371, 2004.

Sarmiento, J. L., and N. Gruber.: Ocean Biogeochemical Dynamics. Princeton University Press, Princeton, NJ, USA, 2006.

Schulz, J.-P., Du menil, L. and Polcher, J.: On the land surface-atmosphere coupling and its impact in a single-column atmospheric model. J. Appl. Meteorol., 40, 642-663, 2001.

Schwinger, J., and Coauthors.: Nonlinearity of ocean carbon cycle feedbacks in CMIP5 Earth system models. Journal of Climate, 27(11), 3869-3888, 2014.

Séférian, R., and Coauthors.: Skill assessment of three earth system models with common marine biogeochemistry. Climate Dynamics, 40(9-10), 2549-2573, 2013.

25 Skinner, L.C., and Coauthors.: Radiocarbon constraints on the glacial ocean circulation and its impact on atmospheric $\mathrm{CO}_{2}$. Nature communications, 8, 16010, 2017.

Stocker, T.F. and Wright, D.G.: Rapid changes in ocean circulation and atmospheric radiocarbon. Paleoceanography, 11(6), 773-795, 1996.

Takahashi, T., Broecker, W.S. and Langer, S.: Redfield ratio based on chemical data from isopycnal surfaces. Journal of Geophysical Research: Oceans, 90(C4), 6907-6924, 1985.

Takahashi, T., and Coauthors.: Climatological mean and decadal change in surface ocean $\mathrm{pCO}_{2}$, and net sea-air $\mathrm{CO}_{2}$ flux over the global oceans. Deep Sea Research Part II: Topical Studies in Oceanography, 56(8-10), 554-577, 2009.

Taylor, K.E.: Summarizing multiple aspects of model performance in a single diagram. Journal of Geophysical Research: Atmospheres, 106(D7), 7183-7192, 2001. 
Geosci. Model Dev. Discuss., https://doi.org/10.5194/gmd-2018-68

Manuscript under review for journal Geosci. Model Dev.

Discussion started: 2 May 2018

(c) Author(s) 2018. CC BY 4.0 License.

(c) (i)

Taylor, K.E., Stouffer, R.J. and Meehl, G.A.: An overview of CMIP5 and the experiment design. Bulletin of the American Meteorological Society, 93(4), 485-498, 2012.

Teng, H., Masutani, S.M., Kinoshita, C.M. and Nihous, G.C.: Solubility of $\mathrm{CO}_{2}$ in the ocean and its effect on $\mathrm{CO}_{2}$ dissolution. Energy conversion and management, 37(6-8), 1029-1038, 1996.

5 Uitz, J., Claustre, H., Gentili, B. and Stramski, D.: Phytoplankton class-specific primary production in the world's oceans: seasonal and interannual variability from satellite observations. Global Biogeochemical Cycles, 24, GB3016, 2010.

Wanninkhof, R.: Relationship between wind speed and gas exchange over the ocean. Journal of Geophysical Research: Oceans, 97(C5), 7373-7382, 1992.

Wanninkhof, R., and Coauthors.: Global ocean carbon uptake: magnitude, variability and trends. Biogeosciences, 10, 19832000, 2013.

Wanninkhof, R., and Triñanes J.: The impact of changing wind speeds on gas transfer and its effect on global air-sea $\mathrm{CO}_{2}$ fluxes. Global Biogeochemical Cycles, 31, 961-974, 2017.

Weaver, A. J., and Coauthors.: Stability of the Atlantic meridional overturning circulation: A model intercomparison. Geophysical Research Letters, 39, L20709, 2012.

Whitney F A.: Nutrient variability in the mixed layer of the subarctic Pacific Ocean, 1987-2010. Journal of Oceanography, 67(4), 481-492, 2011.

Yool, A. and Popova, E.E.: Medusa-1.0: a new intermediate complexity plankton ecosystem model for the global domain. Geoscientific Model Development, 4(2), 381-417, 2011.

Zalesak, S.T.: Fully multidimensional flux-corrected transport algorithms for fluids. Journal of Computational Physics, 31(3), 335-362, 1979.

Zickfeld, K., Eby, M. and Weaver, A.J.: Carbon-cycle feedbacks of changes in the Atlantic meridional overturning circulation under future atmospheric $\mathrm{CO}_{2}$. Global Biogeochemical Cycles, 22, GB3024, 2008.

Zickfeld, K., Eby, M., Matthews, H.D., Schmittner, A. and Weaver, A.J.: Nonlinearity of carbon cycle feedbacks. Journal of Climate, 24(16), 4255-4275, 2011.

\section{Appendix A.}

In this study, we compare the NESM-2.0.1 simulated ocean biogeochemical fields, including nutrients, chlorophyll, marine net primary production (NPP), air-sea $\mathrm{CO}_{2}$ flux, and ocean inventory of anthropogenic $\mathrm{CO}_{2}$ with available observations and data-based estimates.

Data of global ocean distributions of macronutrient concentrations, including nitrate, phosphate and silicate are from World Ocean Atlas 2009 (WOA09, Garcia, et al., 2010). Distribution of dissolved inorganic carbon (DIC) in the ocean is taken from Global Ocean Data Project (Key et al., 2004; Sabine et al., 2004). Both WOA09 and GLODAP data have a horizontal resolution of $1^{\circ} \times 1^{\circ}$ with 33 vertical levels, and represent the climatology in 1990s. The distribution of observed surface ocean 
Geosci. Model Dev. Discuss., https://doi.org/10.5194/gmd-2018-68

Manuscript under review for journal Geosci. Model Dev.

Discussion started: 2 May 2018

(c) Author(s) 2018. CC BY 4.0 License.

(c) (i)

$\mathrm{pCO}_{2}$ and sea-air $\mathrm{CO}_{2}$ flux for a reference year of 2000 is taken from Takahashi et al (2009) that has a spatial resolution of $4^{\circ}$ latitude by $5^{\circ}$ longitude.

Data-based estimate of marine net primary production (NPP) with a horizontal resolution of $1 / 12^{\circ} \times 1 / 12^{\circ}$ from 1998 to 2008 is used in this study (http://www.science.oregonstate.edu/ocean.productivity/index.php ). NPP is calculated based on the

5 Vertically Generalized Production Model (VGPM) which was first proposed by Behrenfeld and Falkowski (1997a, 1997b) and is widely used in the estimate of global marine net primary production. The standard VGPM equation is:

$\mathrm{NPP}=\mathrm{CHL} \times P^{B}{ }_{\text {opt }} \times$ day $_{\text {length }} \times\left(0.66125 \times \frac{\text { par }}{\text { par }+4.1}\right) \times z_{-} e u$

Where CHL represents chlorophyll concentration from Sea-Viewing Wide Field-of-View Sensor from 1998 to 2008 (hereafter Seawifs, Ocean Biology Processing Group, 2014) which is also used to evaluate model-simulated chlorophyll distribution. $P^{B}{ }_{o p t}$ is maximum C fixation rate within a water column that is a function of sea surface temperature (SST) based on a sevenorder polynomial model (Behrenfeld and Falkowski, 1997a, 1997b). SST data used here is from NOAA/AVHRR thermal dataset. par is photosynthetically active radiation that can be directly accessed from Seawifs dataset. day length is the number of hours of day light in situ and $\mathrm{z}_{\mathrm{eu}}$ is euphotic depth calculated by Case I model ( Morel and Berthon, 1989).

To have a direct comparison between NESM-2.0.1 results and observations, we interpolate modeled results to the corresponding grids of observational data using the distance-weighted average remapping method, i.e. $1^{\circ} \times 1^{\circ}$ for nutrients and DIC, and $4^{\circ} \times 5^{\circ}$ for air-sea flux in year of 2000 . Data-based estimates of chlorophyll and NPP is interpolated from $1 / 12^{\circ} \times 1 / 12^{\circ}$ grids to $1^{\circ} \times 1^{\circ}$ grid, and then modeled NPP and chlorophyll is also interpolated to the same grid. 
Geosci. Model Dev. Discuss., https://doi.org/10.5194/gmd-2018-68

Manuscript under review for journal Geosci. Model Dev.

Discussion started: 2 May 2018

(c) Author(s) 2018. CC BY 4.0 License.

(c) (i)

Table 1 Description of the NESM-2.0.1 simulation experiments

Experiment $\quad \mathrm{CO}_{2}$ seen by atmosphere radiation $\quad \mathrm{CO}_{2}$ seen by ocean carbon cycle

$\mathrm{BC} \quad$ Constant pre-industrial $\mathrm{CO}_{2}$ concentration

Prescribed time-varying $\mathrm{CO}_{2}$ concentration

$\mathrm{RC}$ Prescribed time-varying $\mathrm{CO}_{2}$

Pre-industrial $\mathrm{CO}_{2}$

FC

Prescribed time-varying $\mathrm{CO}_{2}$

Prescribed time-varying $\mathrm{CO}_{2}$ concentration

Table 2. Global ocean anthropogenic $\mathrm{CO}_{2}$ uptake simulated by NESM-2.0.1 during different periods compared against data-based estimate (Ciais et al., 2013).

\begin{tabular}{|c|c|c|c|c|c|}
\hline & preindustry-2011 & 1980-1989 & 1990-1999 & $2000-2009$ & $2002-2011$ \\
\hline & Cumulative $\mathrm{PgC}$ & $\mathrm{PgC} \mathrm{yr}^{-}{ }^{1}$ & $\mathrm{PgC} \mathrm{yr}^{-}{ }^{1}$ & $\mathrm{PgC} \mathrm{yr}^{-}{ }^{1}$ & $\mathrm{PgC} \mathrm{yr}^{-1}$ \\
\hline IPCC AR5 & $155 \pm 30$ & $2.0 \pm 0.7$ & $2.2 \pm 0.7$ & $2.3 \pm 0.7$ & $2.4 \pm 0.7$ \\
\hline NESM & 144.4 & 1.7 & 1.9 & 2.3 & 2.3 \\
\hline
\end{tabular}


Geosci. Model Dev. Discuss., https://doi.org/10.5194/gmd-2018-68 Manuscript under review for journal Geosci. Model Dev.

Discussion started: 2 May 2018

(c) Author(s) 2018. CC BY 4.0 License.

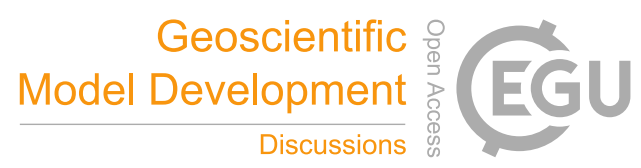

(c) (i)
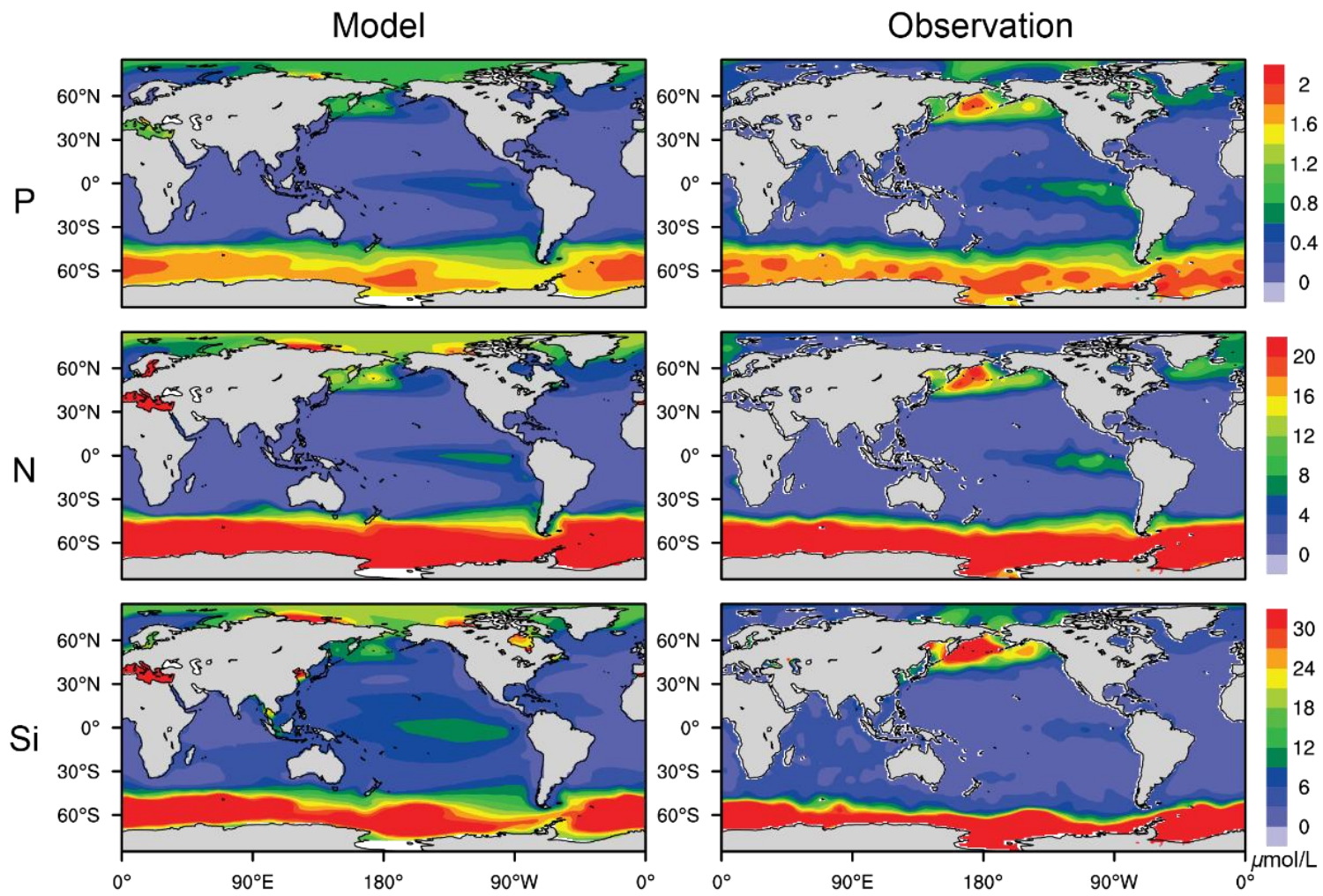

Figure 1: Annual mean surface concentration of phosphate (P), nitrate (N), and silicate (Si) averaged over the 1990s from NESM2.0.1 simulations and WOA09 observation dataset.
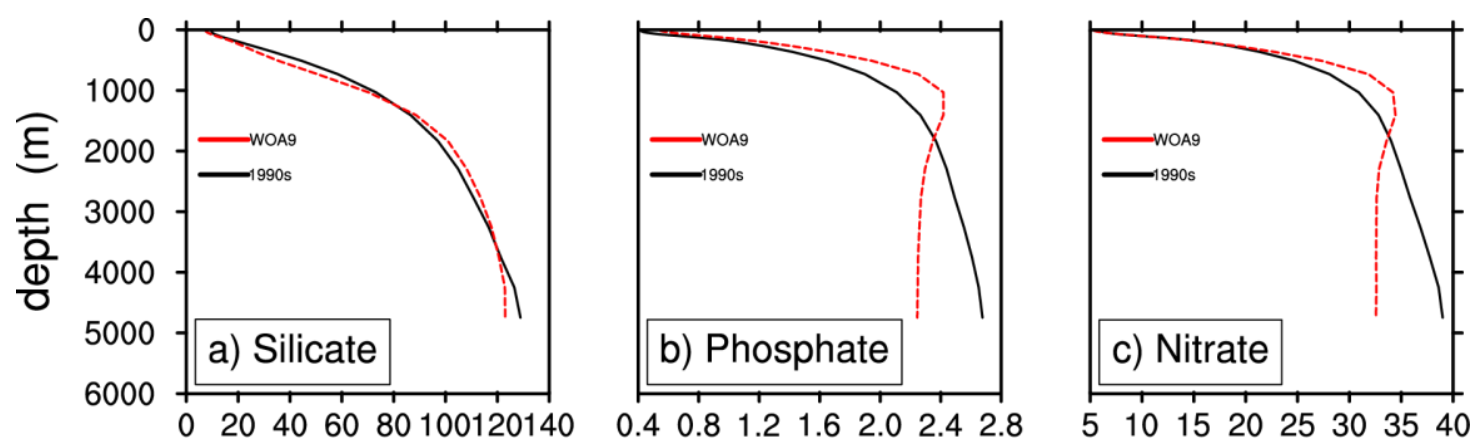

concentration / $\mu \mathrm{M}$

Figure 2: NESM-2.0.1 simulated (black) globally averaged vertical profiles of silicate (a), phosphate (b), and nitrate (c) averaged over 1990s compared with WOA09 observations (red). 
Geosci. Model Dev. Discuss., https://doi.org/10.5194/gmd-2018-68 Manuscript under review for journal Geosci. Model Dev.

Discussion started: 2 May 2018

(c) Author(s) 2018. CC BY 4.0 License.

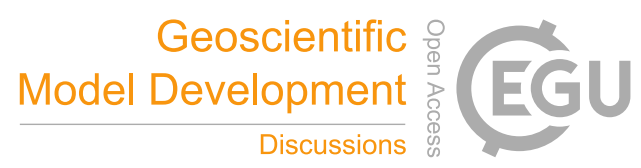

(c) (i)
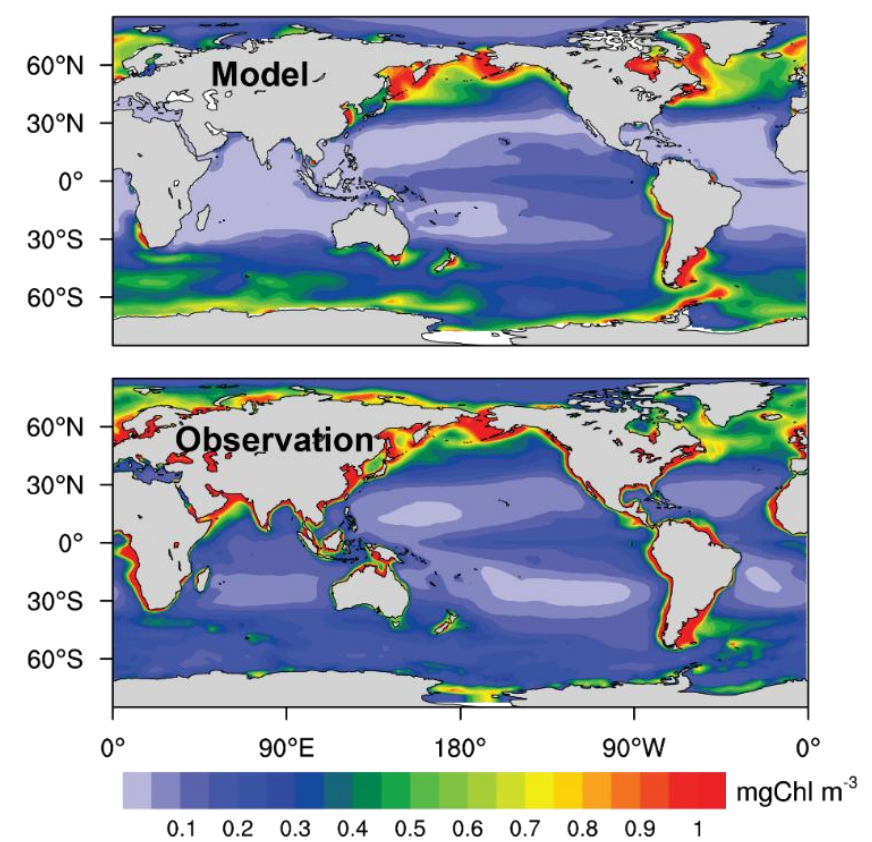

Figure 3: Annual mean surface chlorophyll concentration $\left(\mathrm{mg} \mathrm{Chl} \mathrm{m}^{-3}\right)$ averaged over the 1990s from NESM-2.0.1 simulations and SeaWifs dataset.
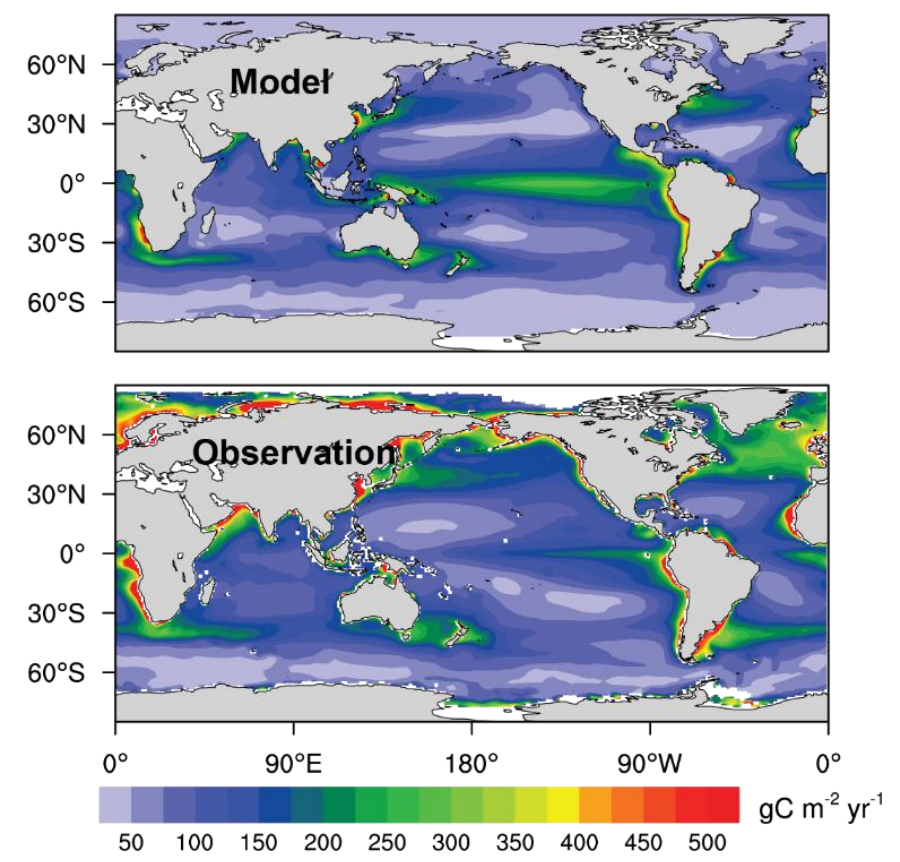

Figure 4: NESM-2.0.1 simulated annual mean distribution of vertical integrated net primary production $\left(\mathrm{g} \mathrm{C} \mathrm{m}^{-2} \mathrm{yr}^{-1}\right) \operatorname{averaged~}$ over 1990s compared with observationally based estimates. 
Geosci. Model Dev. Discuss., https://doi.org/10.5194/gmd-2018-68 Manuscript under review for journal Geosci. Model Dev.

Discussion started: 2 May 2018

(c) Author(s) 2018. CC BY 4.0 License.

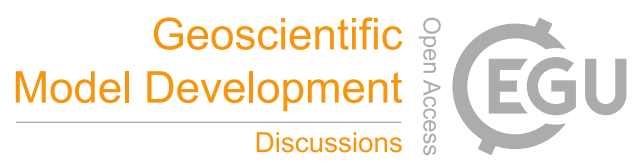
(c)
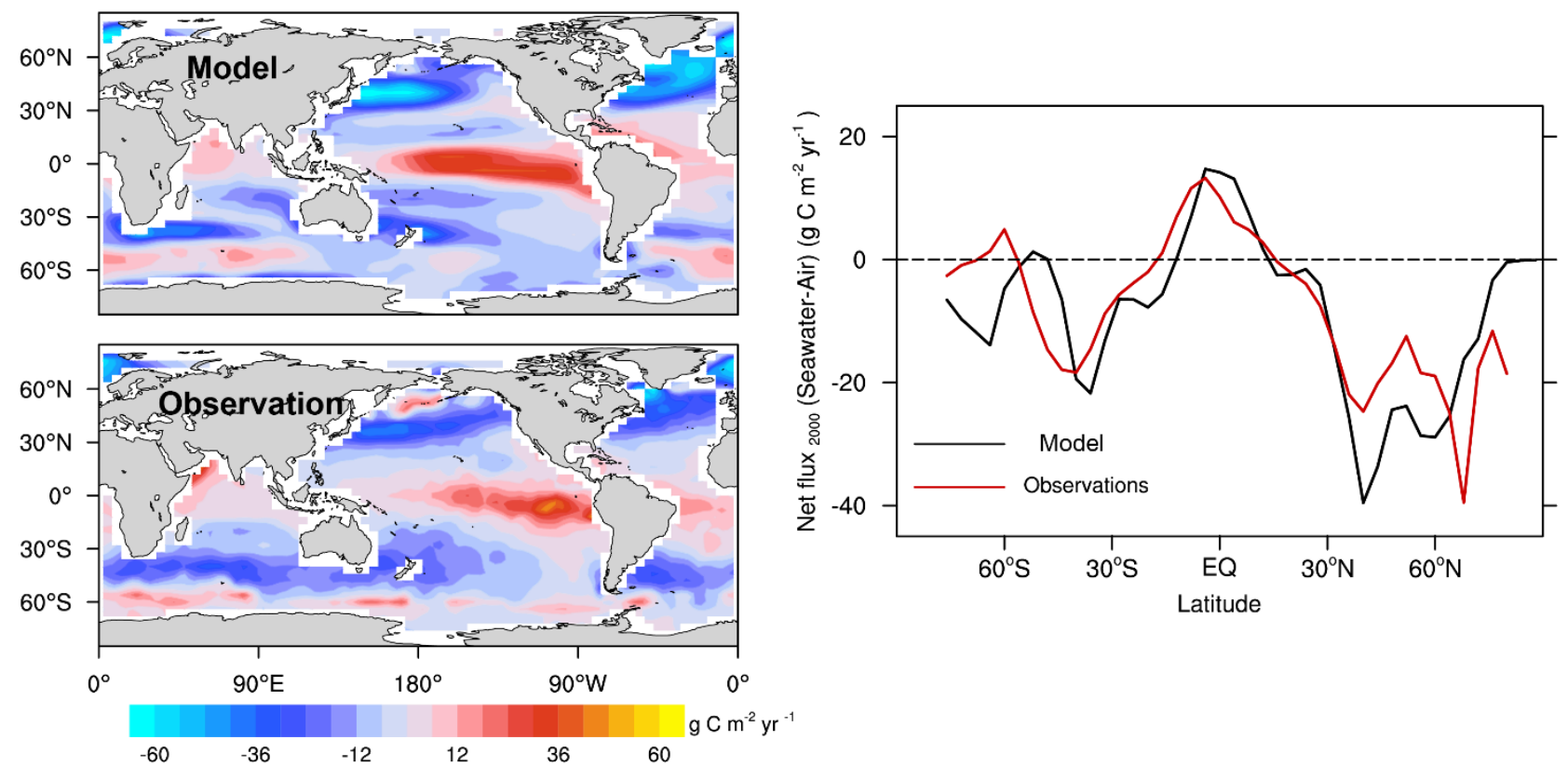

Figure 5: NESM-2.0.1 simulated air-sea $\mathrm{CO}_{2}$ flux $\left(\mathrm{g} \mathrm{C} \mathrm{m}^{-2} \mathrm{yr}^{-1}\right)$ at year 2000 against observational data. Left panels are geographical distribution and right panel is zonal mean pattern. Positive values represent $\mathrm{CO}_{2}$ flux out of ocean, and negative values represent $\mathrm{CO}_{2}$ flux into the ocean
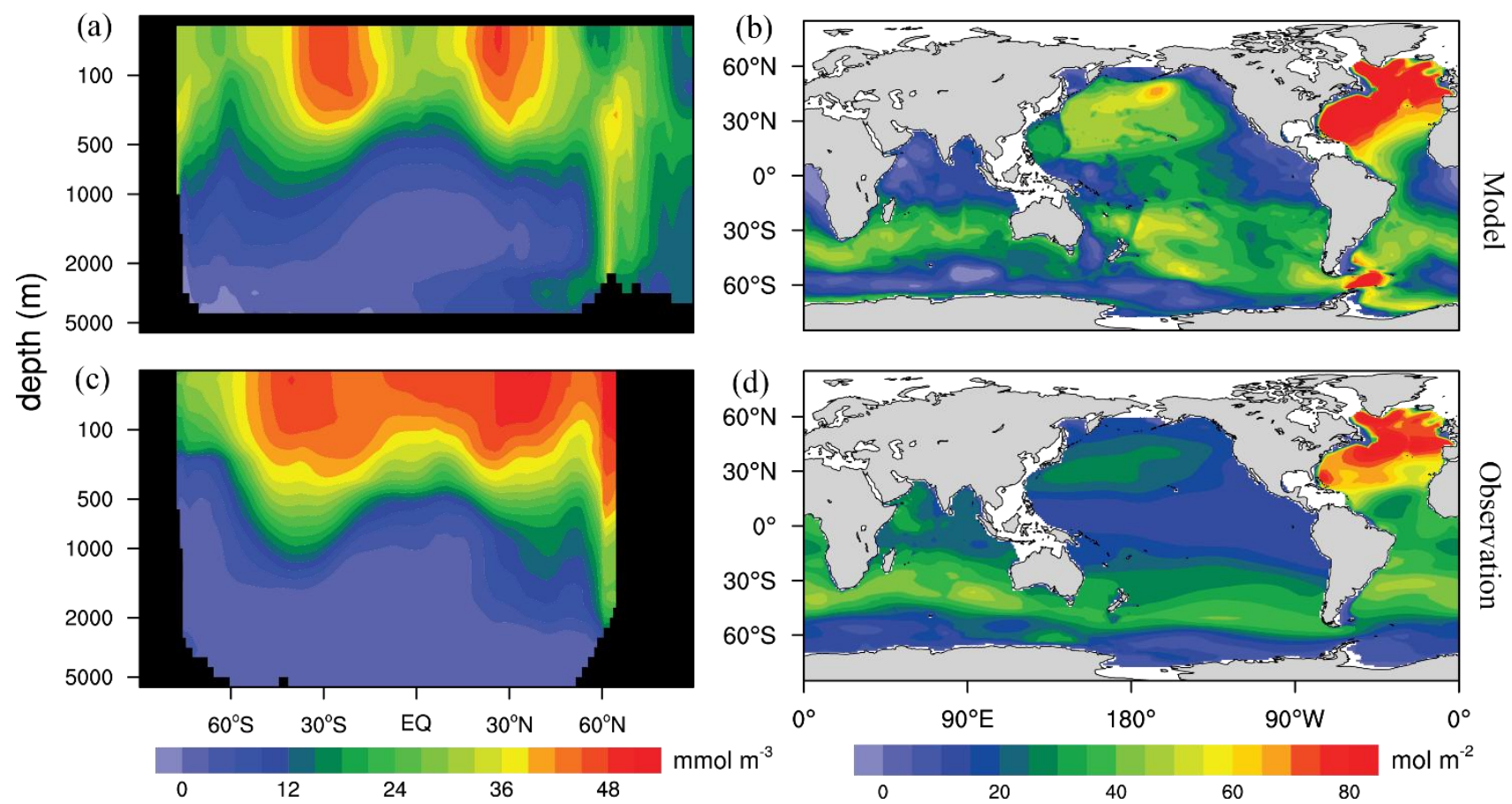

Figure.6: Latitude-depth distribution of anthropogenic $\mathrm{CO}_{2}\left(\mathrm{mmol} \mathrm{m}^{-3}\right)$ from NESM-2.0.1 simulations (a) and data-based estimates (c). Vertically integrated column inventory of anthropogenic $\mathrm{CO}_{2}\left(\mathrm{~mol} \mathrm{~m}^{-2}\right)$ from NESM-2.0.1 simulations (b) and databased estimates (d) 
Geosci. Model Dev. Discuss., https://doi.org/10.5194/gmd-2018-68

Manuscript under review for journal Geosci. Model Dev.

Discussion started: 2 May 2018

(c) Author(s) 2018. CC BY 4.0 License.

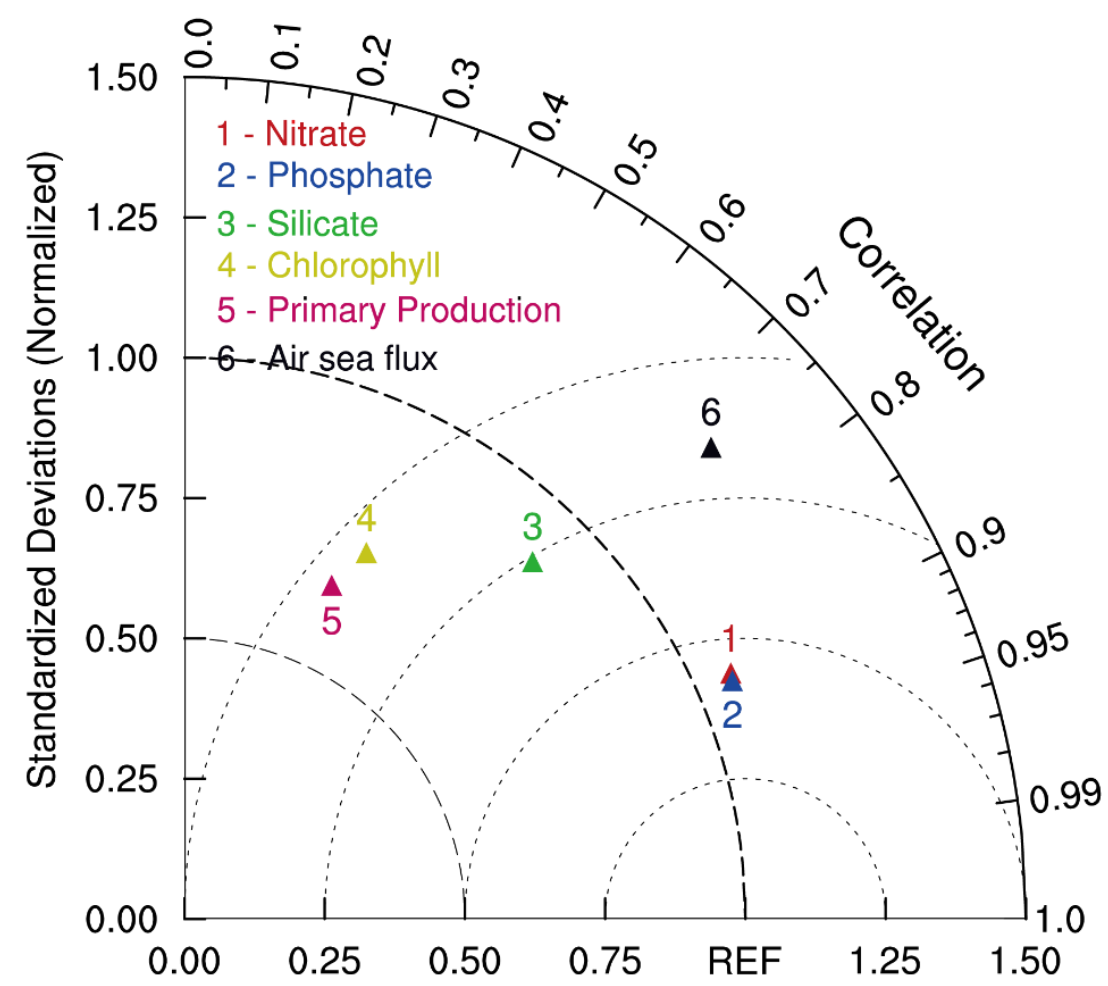

Figure 7: Taylor diagram comparing statistic pattern of annual mean carbon-related fields between NESM-2.0.1 simulations and corresponding observations, including surface nitrate, phosphate, silicate, alkalinity, chlorophyll concentration, verticallyintegrated net primary production, and air-sea $\mathrm{CO}_{2}$ flux. All fields are normalized by the standard deviation of corresponding observations. Thus, observation fields have a standard deviation of one, which is represented by REF. The distance between the model points and the reference point indicate the root-mean-square (RMS) difference between model simulation and observations. 
Geosci. Model Dev. Discuss., https://doi.org/10.5194/gmd-2018-68 Manuscript under review for journal Geosci. Model Dev.

Discussion started: 2 May 2018

(c) Author(s) 2018. CC BY 4.0 License.

\section{(c) (i)}
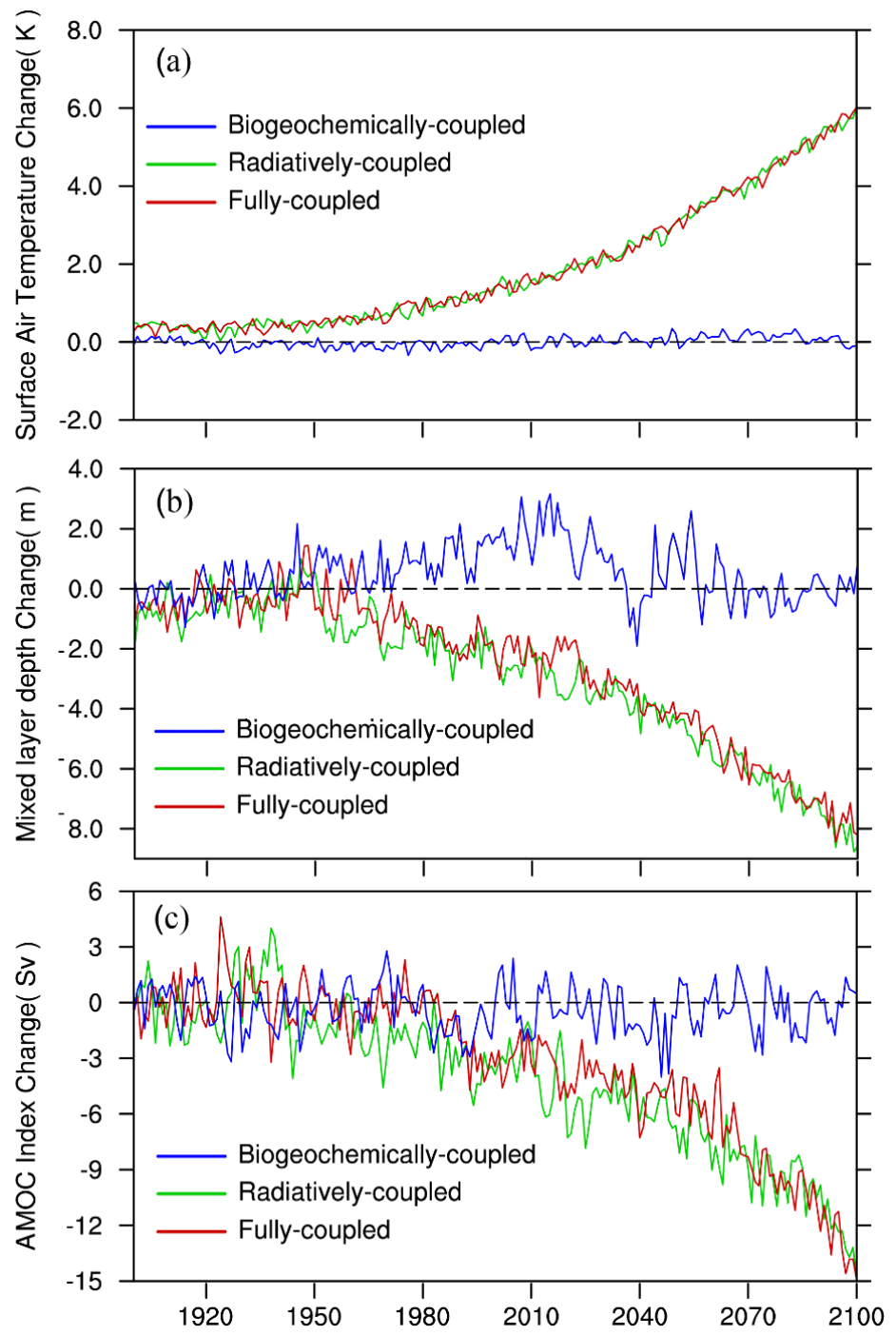

Figure 8: Time series of NESM-2.0.1 simulated changes (relative to pre-industrial) in climate fields under RCP 8.5 scenario for the simulation of fully-coupled, biogeochemically-coupled and radiatively-couple. (a) global and annual mean surface air temperature, (b) global and annual mean mixed layer depth (the depth where the difference in potential density is $0.01 \mathrm{~kg} \mathrm{~m}^{-3}$ relative the sea surface) and (c) Atlantic meridional overturning circulation index (maximum zonal mean stream function of the Atlantic Ocean at $30^{\circ} \mathrm{N}$ ). 
Geosci. Model Dev. Discuss., https://doi.org/10.5194/gmd-2018-68

Manuscript under review for journal Geosci. Model Dev.

Discussion started: 2 May 2018

(c) Author(s) 2018. CC BY 4.0 License.

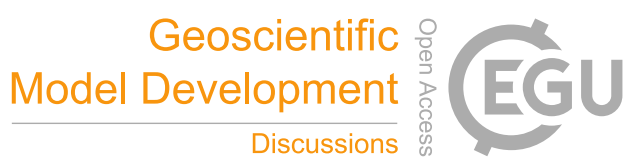

(c)
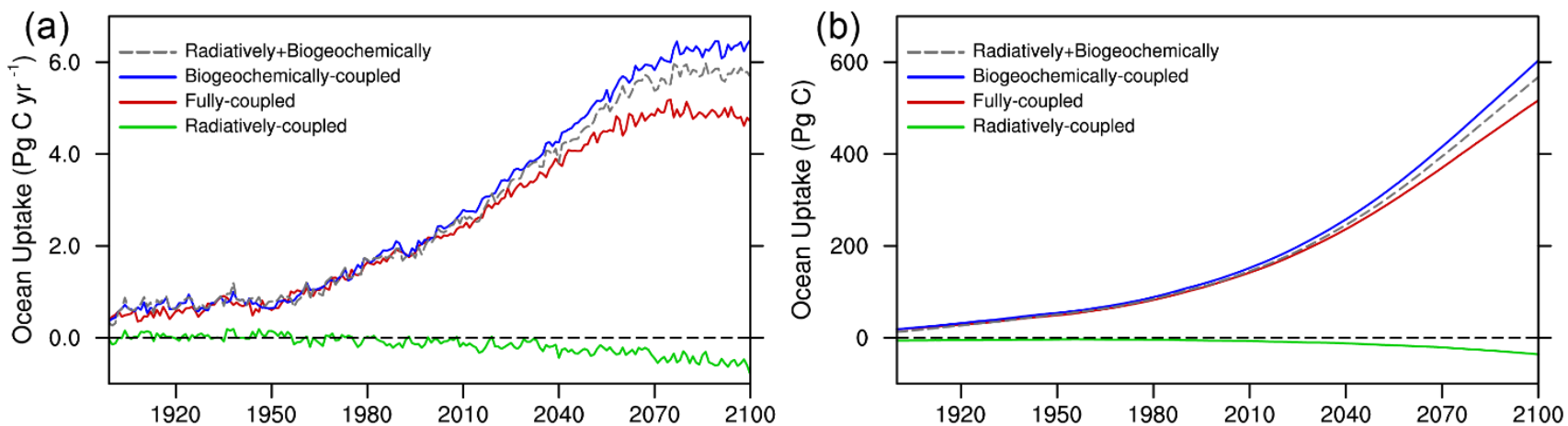

Figure 9. The NESM-2.0.1 simulated (a) annual mean oceanic $\mathrm{CO}_{2}$ uptake and (b) cumulative oceanic $\mathrm{CO}_{2}$ uptake for the simulations of BC (biogeochemical coupled), RC (radiative coupled), FC (fully coupled), and the linear sum of BC and RC under the RCP 8.5 scenario.
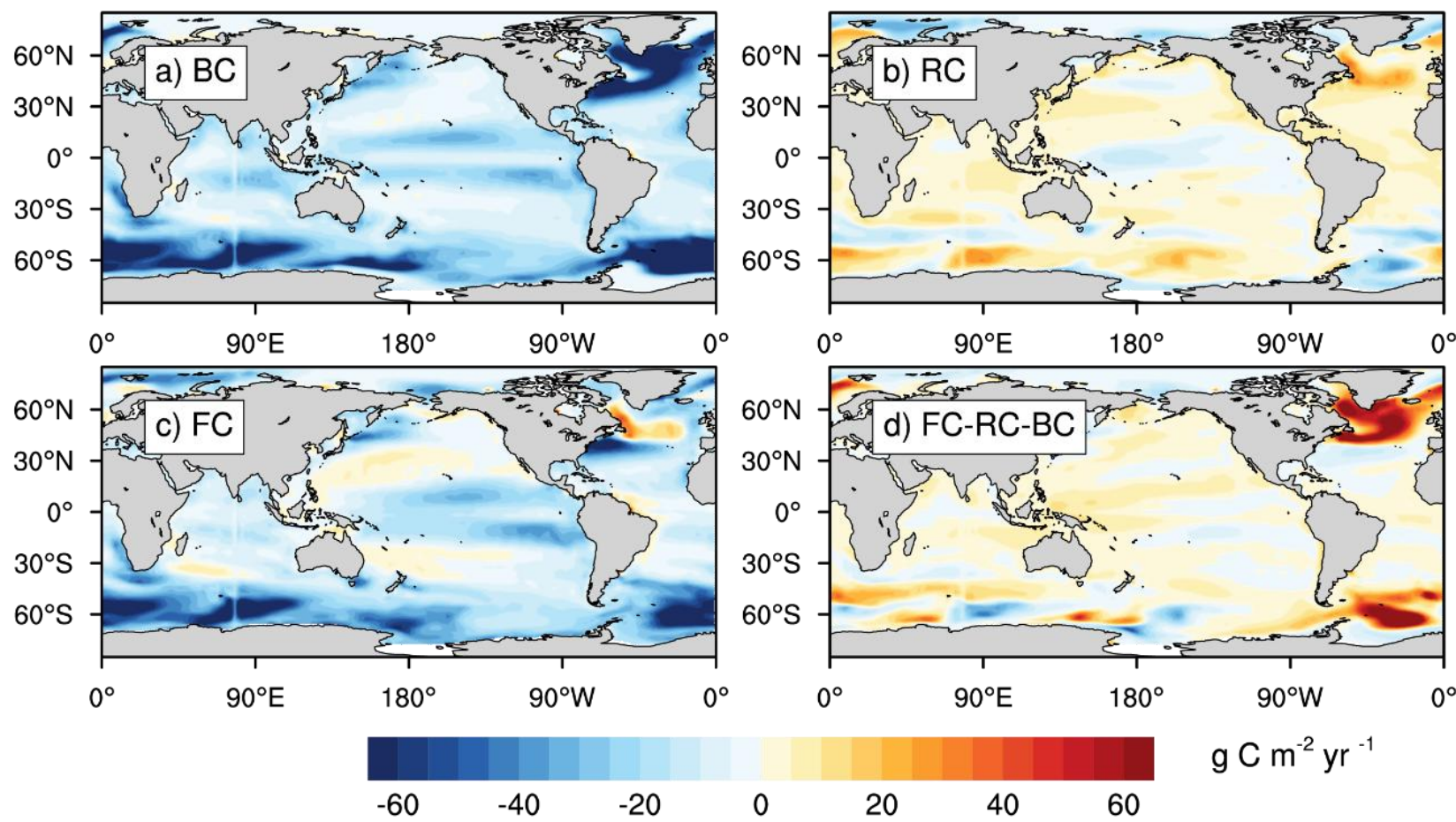

Figure 10. Spatial distribution of anthropogenic air-sea $\mathrm{CO}_{2}$ flux at the end of 21th century (averaged over year 2091 to 2100$)$ under RCP8.5 scenario for BC (biogeochemically coupled), RC (radiatively coupled), and FC (fully coupled) simulations, respectively. Also shown is the difference between $\mathrm{FC}$ simulation and the sum of RC and BC simulations (FC-RC-BC). Positive values represent $\mathrm{CO}_{2}$ flux out of ocean, and negative values represent $\mathrm{CO}_{2}$ flux into the ocean. 
Geosci. Model Dev. Discuss., https://doi.org/10.5194/gmd-2018-68

Manuscript under review for journal Geosci. Model Dev.

Discussion started: 2 May 2018

(c) Author(s) 2018. CC BY 4.0 License.

(c) (i)
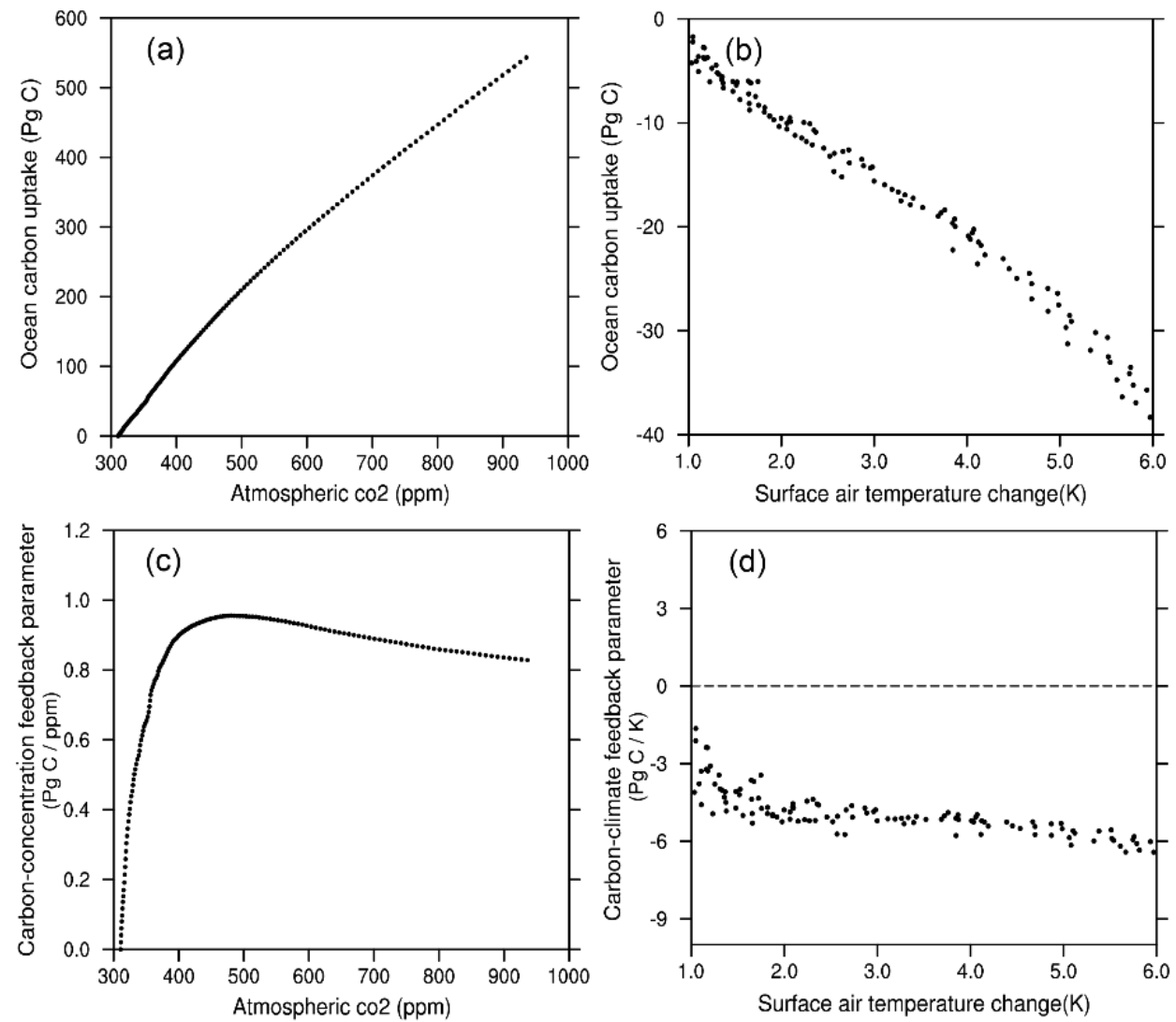

Figure 11: The NESM-2.0.1 simulated cumulated ocean uptake against (a) the atmospheric CO2 in the BC experiment and (b) the global mean surface air temperature change in the RC experiment. Also shown is time evolution of diagnosed carbonconcentration feedback parameter as a function of atmospheric $\mathrm{CO} 2$ (c) and carbon-climate feedback parameter as a function of global mean surface air temperature change (d).
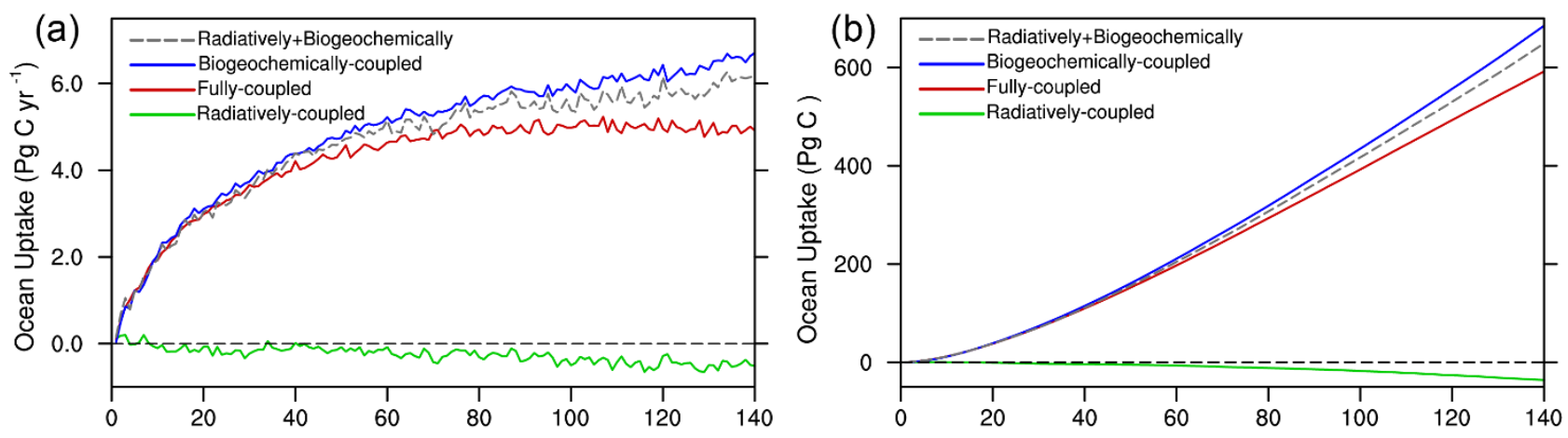

Figure 12: Same as Figure 9, but for $1 \%$ per year $\mathrm{CO}_{2}$ increase run. 
Geosci. Model Dev. Discuss., https://doi.org/10.5194/gmd-2018-68 Manuscript under review for journal Geosci. Model Dev.

Discussion started: 2 May 2018

(c) Author(s) 2018. CC BY 4.0 License.

(c) $\underset{\mathrm{BY}}{(i)}$
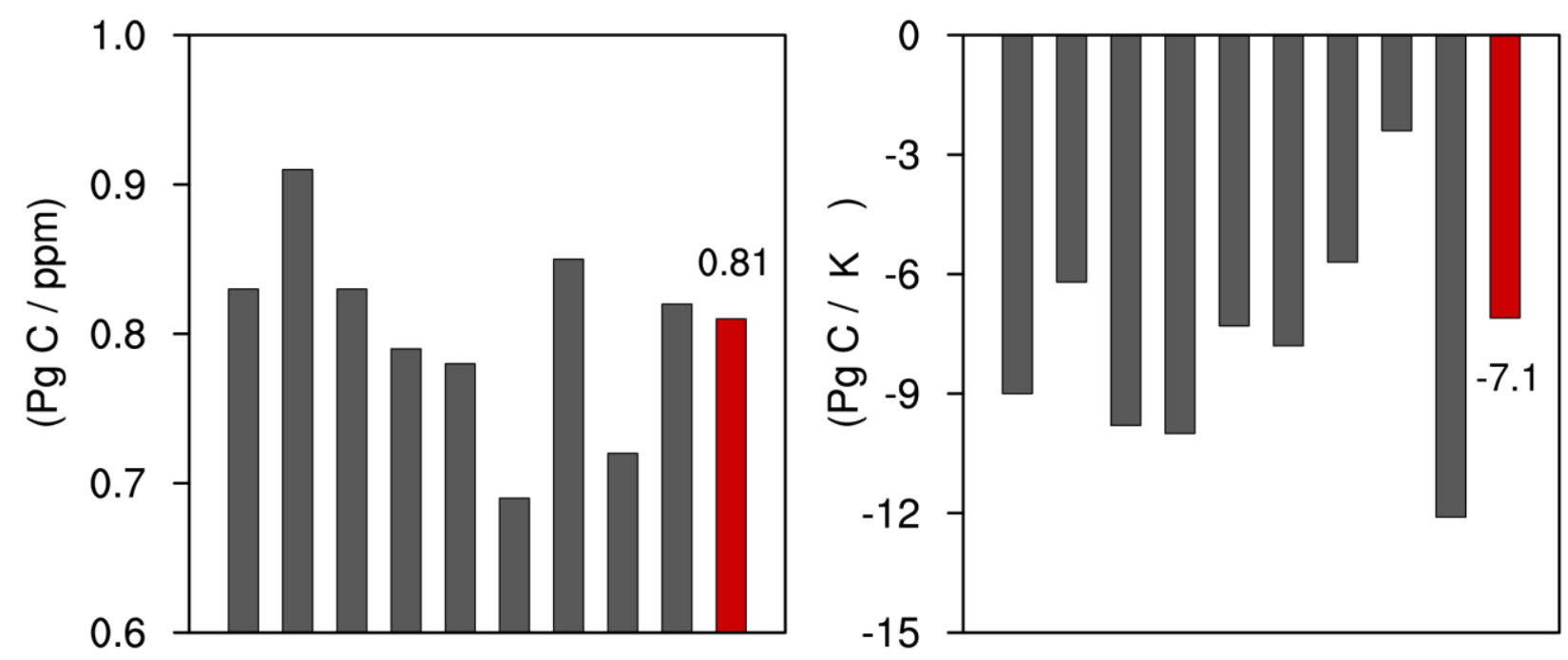

Figure 13: Carbon-concentration feedback parameter (left panel) and carbon-climate feedback parameter (right-panel) diagnosed from CMIP5 and NESM-2.0.1 benchmark simulations with the increase of atmospheric $\mathrm{CO}_{2}$ at a rate of $1 \%$ per year. $\mathrm{CMIP5}$ model results are in grey, and NESM-2.0.1 results are in red. CMIP5 models includes MPI-ESM-LR, IPSL-CM5A-LR, BCCCSM1, HADGEMS, UVicESCM2.9, CanESM2, NorESM-ME, CESM1-BGC and MIROC ESM (from left to right). 